Universidad de Lima

Escuela de Posgrado

Maestría de Derecho Empresarial

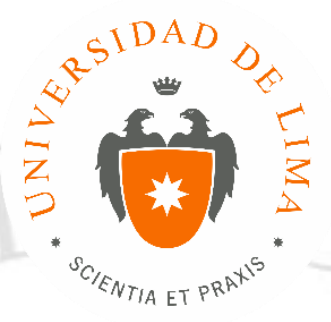

\title{
DEFICIENCIAS DEL PROCEDIMIENTO ADMINISTRATIVO SANCIONADOR AL SECTOR EMPRESARIAL PESQUERO POR PARTE DEL MINISTERIO DE LA PRODUCCIÓN DE PERÚ
}

Trabajo de investigación para optar el Grado Académico de Maestro en Derecho Empresarial

\section{Hugo Alonso Diaz Diaz}

Código: 20062205

Asesor Técnico

Miguel Eduardo Puga de la Rocha

Lima, Perú

Julio - 2017 


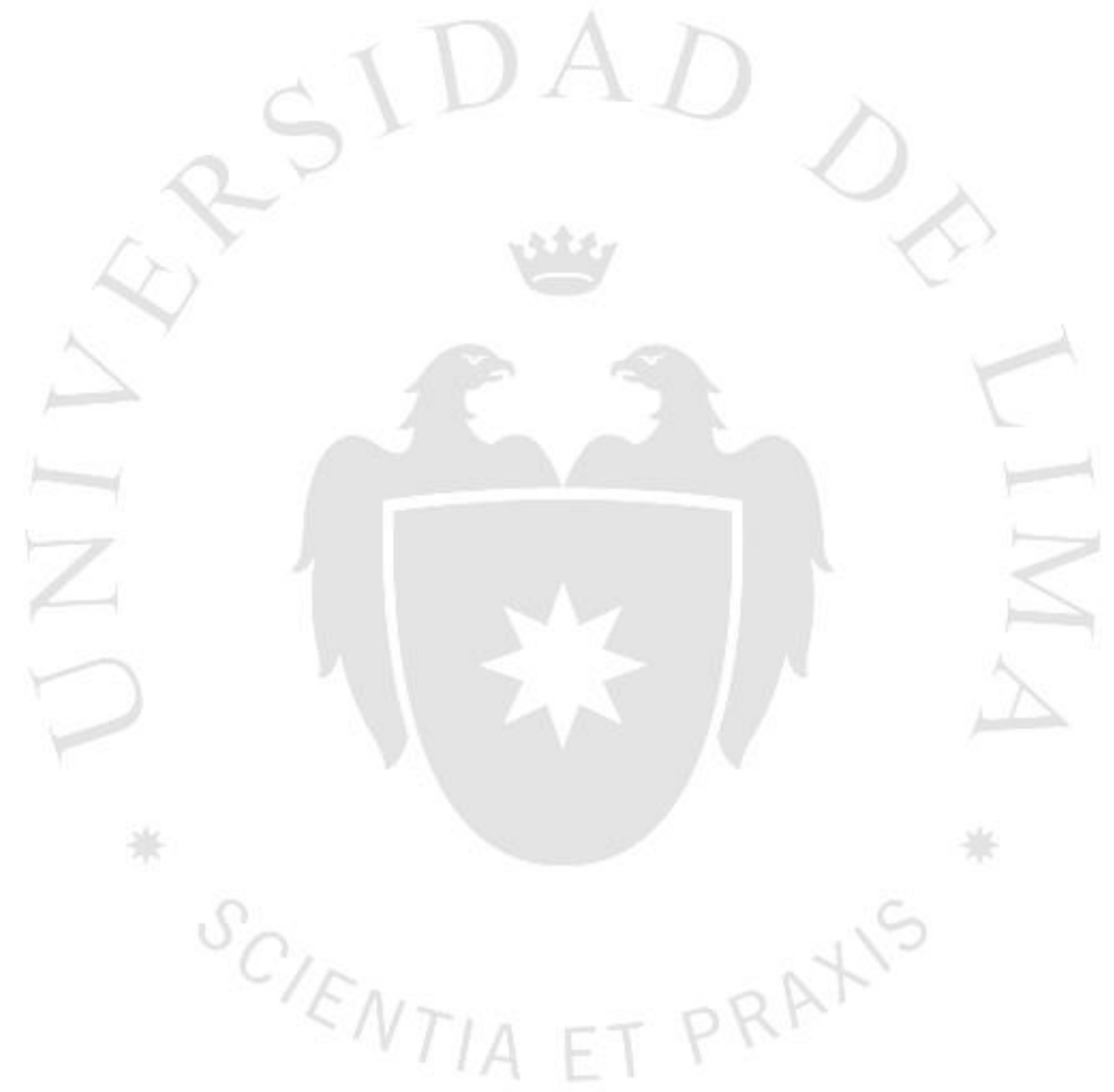




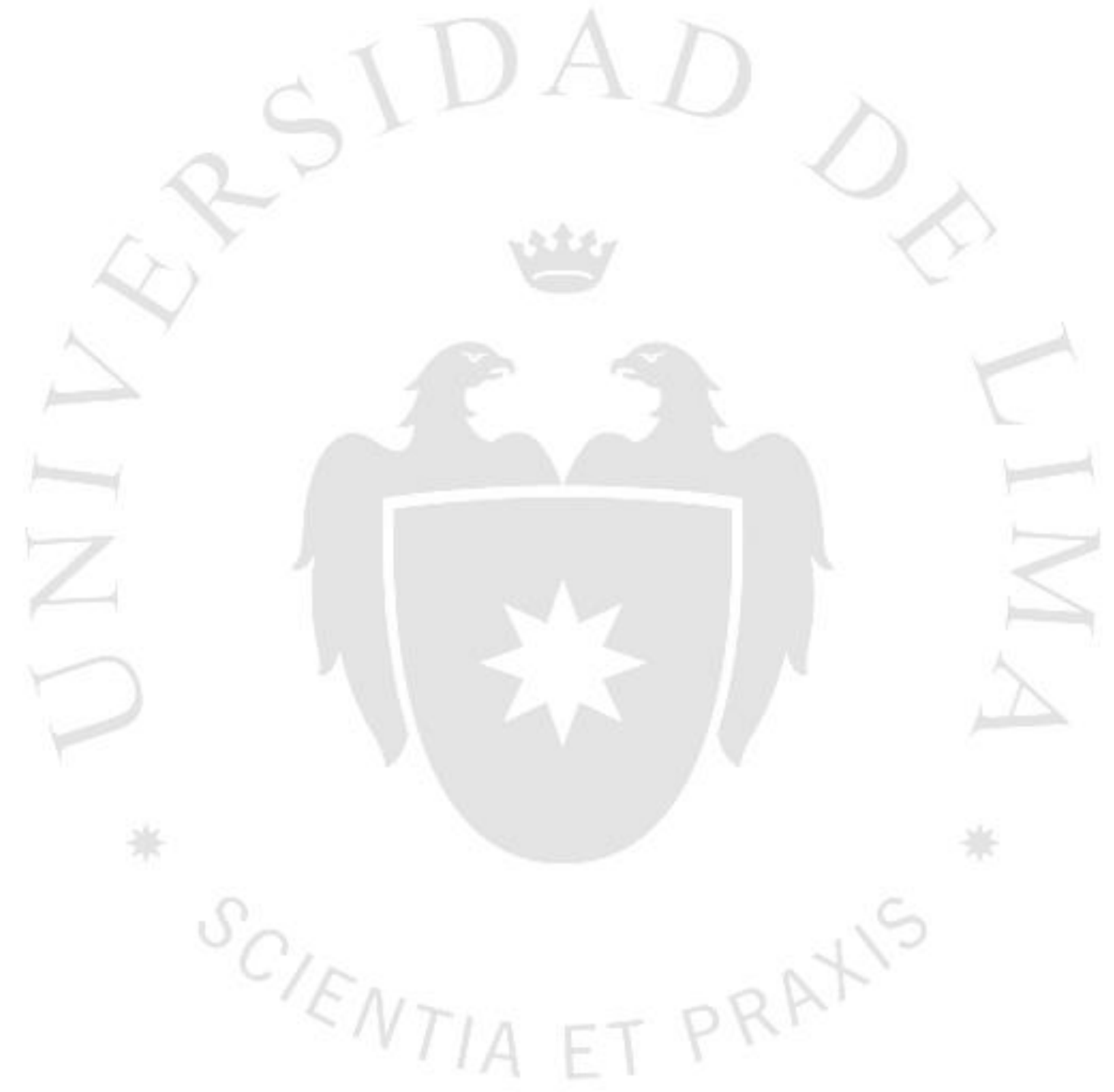




\section{DEFICIENCIAS DEL PROCEDIMIENTO}

ADMINISTRATIVO SACIONADOR AL SECTOR EMPRESARIAL PESQUERO POR PARTE DEL MINISTERIO DE LA PRODUCCIÓN DE PERÚ 


\section{TABLA DE CONTENIDO}

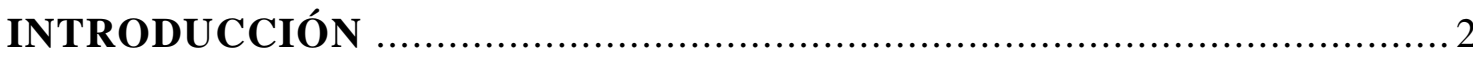

CAPITULO I: ASPECTOS CONCEPTUALES ................................. 9

1.1 Principios constitucionales vulnerados por las fórmulas de las sanciones aplicadas en el procedimiento administrativo sancionador ....9

1.2 Elementos jurídicos, funcionales y de competencia sobre las sanciones en Pesquería.......................................................... 17

$1.3 \mathrm{El}$ control Difuso ........................................................... 20

CAPITULO II: EL PROCEDIMIENTO ADMINISTRATIVO SANCIONADOR DE EMPRESAS PESQUERAS ............................... 32

2.1 Causales de sanción de multa ............................................ 32

2.2 El tipo del numeral 18), la falta de Técnica Legislativa aplicada a la fórmula de la sanción de multa y el caso EMPRESA CANTABRIA S.A.

2.3 Las dificultades entre la aplicación de la norma y la realidad pesquera

CAPÍTULO III EL IMPACTO DE LA SANCIÓN HACIA EL SECTOR EMPRESARIAL PESQUERO

3.1 Perjuicios económicos al desarrollo empresarial pesquero 43

3.2 Negativa del sector empresarial pesquero al pago de la sanción de multa 45

CAPÍTULO IV LA RESPUESTA DEL SECTOR EMPRESARIAL PESQUERO ANTE LA IMPOSICIÓN DE LA SANCIÓN DE MULTA ..... 47

4.1 Recurso de Apelación en el procedimiento administrativo sancionador y la demanda de nulidad de la resolución correspondiente por parte del sector empresarial pesquero ante el Poder Judicial (Contencioso Administrativo) 
4.2 El Control Difuso como mecanismo de resolución de controversias

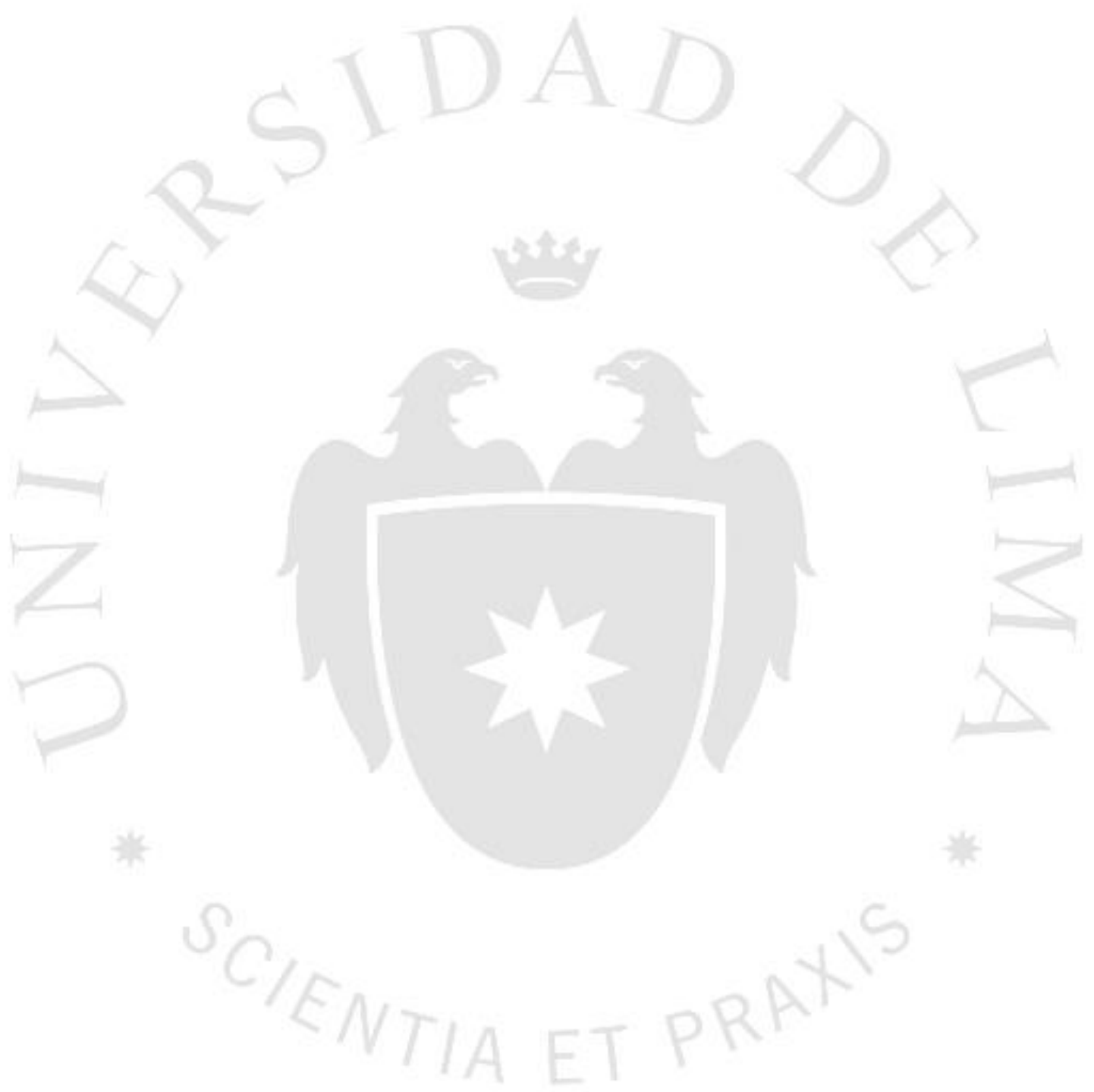




\section{ÍNDICE DE FIGURAS}

Figura 2.1: Producción pesquera expresada en Nuevos Soles 2016...............40

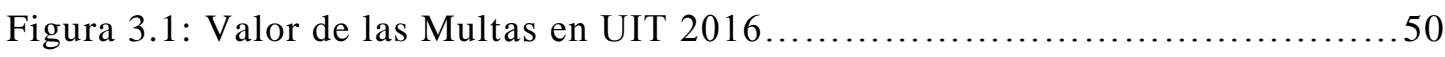

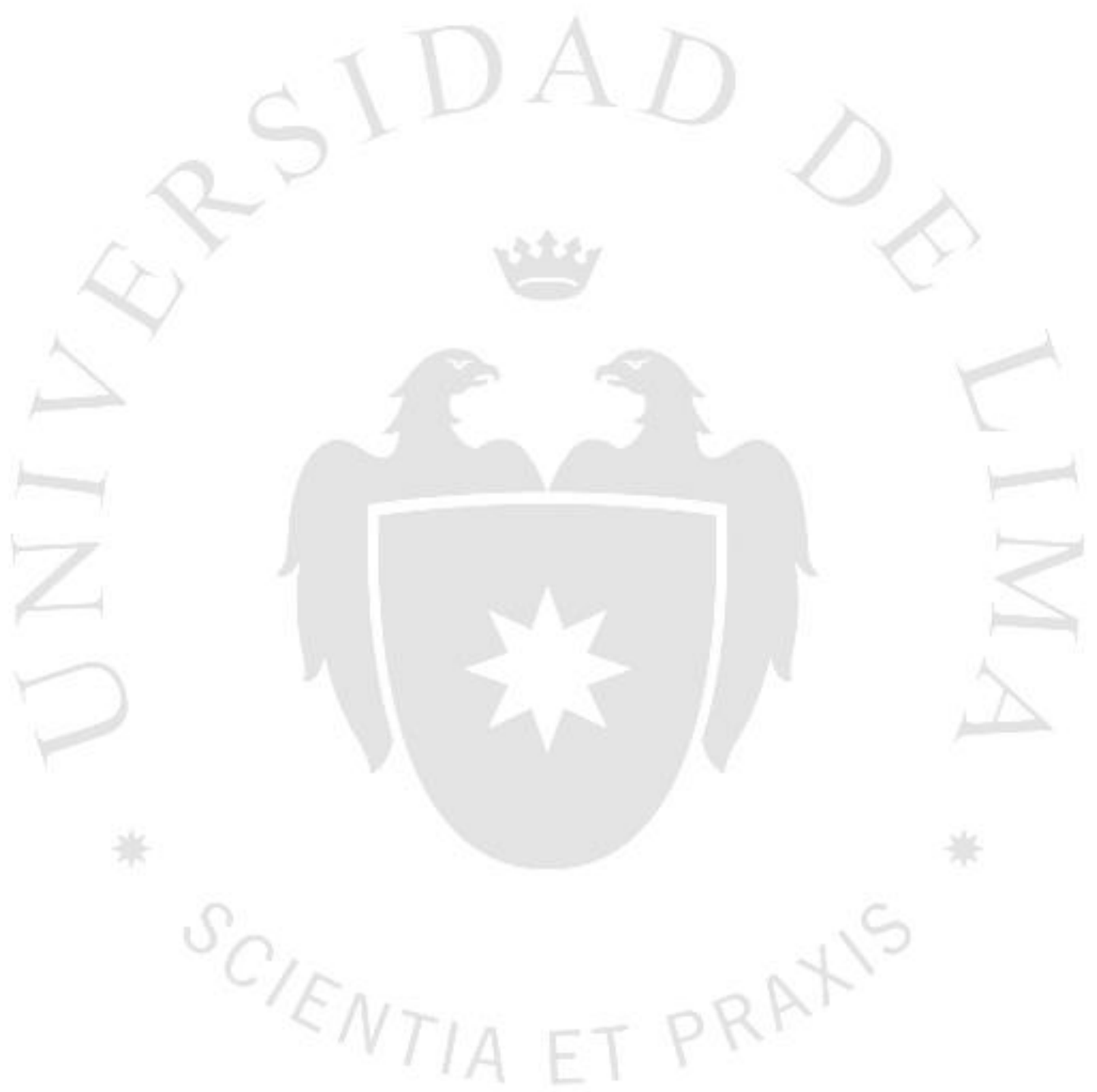




\section{ÍNDICE DE TABLAS}

Tabla 2.1: Tabla Resumen de Sanciones....................................... 36

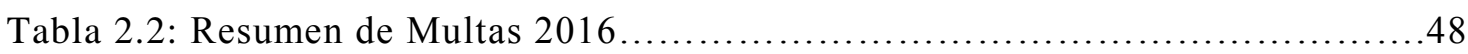




\section{INTRODUCCIÓN}

Según señala el Texto Único Ordenado de la Ley del Procedimiento Administrativo General $N^{\circ}$ 27444, aprobado por el Decreto Supremo $N^{\circ} 006$ 2017-JUS, en el Título IV, del Procedimiento Trilateral, del Procedimiento Sancionador y la Actividad Administrativa de Fiscalización, Capitulo III del Procedimiento Sancionador, en el artículo $245^{\circ}$ se establece la facultad que tienen las entidades para establecer infracciones y sanciones administrativas. En el artículo $253^{\circ}$ se indica que mediante resolución que aplique la sanción o la decisión de archivar el procedimiento, se notifica al administrado.

Cada entidad que implementa un Procedimiento Administrativo Sancionador (PAS) puede realizarlo de dos (02) formas:

- La aplicación del PAS bajo lo regulado entre los artículos $245^{\circ}$ y $257^{\circ}$ del Texto Único Ordenado de la Ley del Procedimiento Administrativo General № 27444, aprobado por el Decreto Supremo Nº06-2017-JUS.

- La creación de reglamentos especiales que permitan implementar el PAS de acuerdo a la materia especifica.

En el caso particular del Ministerio de la Producción, el PAS se aplica de acuerdo al Texto Único Ordenado del Reglamento de Inspecciones y Sanciones Pesqueras y Acuícolas (TUO del RISPAC), el cual fue aprobado por el Decreto Supremo $\mathrm{N}^{\circ}$ 019-2011-PRODUCE. De acuerdo al Reglamento de Organización y Funciones (ROF), aprobado por el Decreto Supremo Nº02-2017-PRODUCE, la administración del PAS se aplica a nivel resolutivo en primera instancia en la Dirección de Sanciones (DS-PA), del Viceministerio de Pesca y Acuicultura del Ministerio de la Producción.

El PAS en el Ministerio de la Producción, en particular, en las áreas vinculadas a la regulación pesquera tiene finalidades de control sobre la extracción de recursos hidrobiológicos y adecuado desarrollo del sector pesquero, sin embargo, su implementación muchas veces puede ser incompatible con la actividad de promoción empresarial propia de este Ministerio. En ese 
sentido, una investigación de Héctor Rojas (2014) considera que los PAS deben tener límites constitucionales, pues el poder sancionador público no debe exceder las normas de un Estado Social y Democrático de Derecho.

La DS-PA, aplica algunas de las sanciones establecidas en el TUO del RISPAC a las embarcaciones pesqueras siguiendo complejos criterios técnicos establecidos en el Decreto Supremo N 001-2014-PRODUCE. Dicho Decreto Supremo, aprobó el nuevo Reglamento del Sistema de Seguimiento Satelital para embarcaciones pesqueras, el cual se encuentra basado en el seguimiento satelital, es decir, se trata del seguimiento constante y automatizado que realizan los equipos satelitales a los GPS ubicados en las embarcaciones pesqueras. Este sistema detecta infracciones de diversos tipos como pescar en zonas prohibidas, impedir la transmisión de los equipos de seguimiento, presentar códigos de manipulación, distorsión o señales de posición congeladas, entre otros.

El Sistema de Seguimiento Satelital (SISESAT), se crea con la aprobación de su Reglamento, mediante el Decreto Supremo Nº 026-2003-PRODUCE, con el objeto de: i) Adoptar medidas de ordenamiento pesquero y aprovechamiento responsable de los recursos hidrobiológicos, ii) Complementar las acciones de seguimiento, control y vigilancia de las actividades extractivas, iii) Preservar los recursos hidrobiológicos cuyo ecosistema se desarrolla dentro de la zonas reservadas por el Ministerio de la Producción.

Posteriormente con Decreto Supremo N 001-2014-PRODUCE, se derogo el Decreto Supremo N ${ }^{\circ}$ 26-2003-PRODUCE que creo el Sistema de Seguimiento Satelital y se aprobó el nuevo Reglamento de SISESAT para Embarcaciones Pesqueras, el cual de acuerdo a su artículo $4^{\circ}$, es de aplicación a las embarcaciones de bandera nacional o extranjera de mayor escala y a las embarcaciones pesqueras de menor escala que realizan actividades extractivas del recurso anchoveta, obligándolas a contar con el mencionado sistema en virtud al ordenamiento pesquero especifico.

De acuerdo al numeral b) del artículo $87^{\circ}$ del Reglamento de Organización y Funciones del Ministerio de la Producción, aprobado por el Decreto Supremo $\mathrm{N}^{\circ}$ 002-2017-PRODUCE, el SISESAT, se encuentra a cargo de la Dirección de Supervisión y Fiscalización del Vice Ministerio de Pesca y Acuicultura del 
Ministerio de la Producción, la cual apoyándose de esta herramienta tecnológica realiza su función de supervisar y fiscalizar el cumplimiento del ordenamiento pesquero, así como el cumplimiento de los derechos otorgados.

Cuando se detecta una infracción en alguna de las embarcaciones pesqueras por manipulación de los equipos SISESAT, el sistema emite un reporte con códigos y cortes de señal que indican en que tipo presuntamente de infracción se incurrió. De incurrir en el tipo de infracción del numeral 18 del Reglamento de la Ley General de Pesca, aprobado por el Decreto Supremo N 012-2001PE, la sanción de multa a pagar por parte de los administrados (personas naturales o jurídicas), se determinan bajo la fórmula de multiplicar por ocho (08) veces la capacidad de bodega de la embarcación pesquera en metros cúbicos (m3), ello emitirá el total en Unidades Impositivas Tributarias (UIT) que los administrados deben de pagar.

El procedimiento es funcional por la automatización del sistema, sin embargo, existen sanciones que pueden resultar en sumas exorbitantes que en algunas condiciones llevarían a los administrados a la quiebra o una reestructuración. Es decir, existe una incompatibilidad entre la labor de promoción empresarial del Ministerio de la Producción y su órgano sancionador en materia pesquera.

En el caso específico de los Sub-códigos 18.1 y 18.3 del Código 18, del Cuadro de Sanciones señalado por el artículo $47^{\circ}$ del TUO del RISPAC, aprobado por el Decreto Supremo $\mathrm{N}^{\circ}$ 019-2011-PRODUCE, modificado por el Decreto Supremo $\mathrm{N}^{\circ}$ 009-2013-PRODUCE, se establece un criterio técnico de sanción por las siguientes causales:

- 18.1 Presentar códigos de manipulación o distorsión desde los equipos del SISESAT.

- $\quad$ 18.3 Impedir por cualquier medio o acto la trasmisión de los equipos de SISESAT de manera tal que se interrumpa la señal por un intervalo mayor a dos horas, operando fuera de puertos y fondeaderos.

Las multas impuestas por estas sanciones se establecen bajo el criterio técnico de multiplicar por ocho (08) veces la capacidad de bodega en metros cúbicos 
(m3), en UIT $^{1}$, el resultado del valor de las multas suele ser exorbitante vulnerando el principio constitucional de Razonabilidad. Durante el año 2016, la anterior Dirección General de Sanciones (hoy DS-PA), emitió 84 Resoluciones Directorales sancionatorias que multaban a distintas empresas en los regímenes establecidos en el Decreto Ley $N^{\circ} 25977$ (37 resoluciones) y Ley N ${ }^{\circ} 26920$ (47 resoluciones) por un total de S/ 179,203,224.75 (CIENTO SETENTA Y NUEVE MILLONES DOSCIENTOS TRES MIL DOSCIENTOS VEINTICUATRO CON 75/100 SOLES), siendo la sanción de multa más alta la impuesta a la empresa PESQUERA CANTABRIA S.A., por un total de 3,193.040 UIT.

Debido al alto valor de la sanción de la multa, estas Resoluciones Directorales sancionatorias muchas veces son apeladas por los administrados y elevadas a la segunda instancia que se encarga de resolver los recursos de apelación en última instancia administrativa, confirmando o declarando la nulidad de la decisión inicial de la DS-PA. Ante ello, en el caso de confirmar las Resoluciones Directorales sancionatorias, los propietarios o poseedores de las embarcaciones pesqueras llevan su caso al Poder Judicial vía contencioso administrativo extendiendo el proceso por lapsos de tiempo indeterminados que generan perjuicio a los litigantes, saturación del sistema de justicia y sobre carga administrativa en el Ministerio.

Durante el año 2016 en la Dirección General de Sanciones (hoy DS-PA) del Ministerio de la Producción se sanciono con multa respecto de los Subcódigos 18.1 y 18.3 , previo PAS a 84 empresas dedicadas a la actividad pesquera, sin embargo, dichas sanciones habrían sido apeladas por parte de los administrados hasta agotar la vía administrativa y de ser el caso llegar a algún Juzgado o Tribunal del Órgano Jurisdiccional. Dicho proceso además de extenso genera sobre carga en los Poderes Ejecutivo y Judicial, además de las pérdidas a nivel empresarial y económico. Es decir, que la labor de promoción empresarial del Ministerio se presenta como una paradoja al intentar hacer ejercicio de sus procedimientos sancionadores.

\footnotetext{
${ }^{1}$ Texto Único Ordenado del Reglamento de Inspecciones y Sanciones Pesqueras y Acuícolas, modificado por el Decreto Supremo N 009-2013-PRODUCE.

Cuadro de Sanciones

Sub-código 18.1: 8 x (Capacidad de bodega en m3) en UIT

Sub-código 18.3: 8 x (Capacidad de bodega en m3) en UIT
} 
Ante este contexto, es necesario desarrollar una investigación sobre la aplicación de este PAS por parte del Ministerio de la Producción en las empresas de rubro pesquero para analizar los problemas de incompatibilidad entre la sanción y la promoción empresarial.

El principio de las sanciones es generar que los actores del sector atiendan sus faltas tomando medidas correctivas, por ello las sanciones que se imponen deben ser proporcionales al incumplimiento calificado como infracción, tomando en cuenta la realidad económica de las empresas, así como analizar su rol en la economía nacional, sin embargo, el PAS del Ministerio de la Producción en materia pesquera no considera estas directrices estableciendo multas que afectan a las personas naturales y jurídicas (empresas) del rubro pesquero y que podrían afectar al desarrollo económico en ese sector. Dicha formulación nos llevó a preguntarnos ¿Cuáles son los problemas que presenta el Procedimiento Administrativo Sancionador del Ministerio de la Producción en materia pesquera?

Ante esta interrogante planteamos como supuesto de investigación o hipótesis de la misma que el Procedimiento Administrativo Sancionador del Ministerio de la Producción estableció una sanción de elevada cuantía debido a errores en el diseño de la fórmula de la multa, que han generado problemas legales y económicos a las personas naturales y jurídicas (empresas) del rubro pesquero.

Debido a ello se consideró importante que el objetivo general de este trabajo de investigación sería determinar los problemas que presenta el Procedimiento Administrativo Sancionador (PAS) del Ministerio de la Producción en el caso de las infracciones a las empresas pesqueras. Dicha consideración metodológica ha requerido desagregar algunos aspectos específicos como son describir con detalle las cualidades y características establecidas en el PAS del Ministerio de la Producción en materia pesquera, analizar los problemas técnicos y jurídicos de las sanciones de multas impuestas por parte del PAS del Ministerio de la Producción y determinar la incompatibilidad entre el rol de promoción empresarial del Ministerio de la Producción y su organismo sancionador en el rubro pesquero. 
Los objetivos presentados son los lineamientos que determinaron la investigación de manera global, pues han permitido ampliar conocimientos en el debate jurídico respecto a este principio legal.

Esta investigación está dividida en seis (06) secciones o capítulos. En el primer capítulo se desarrollan aspectos teóricos conceptuales sobre los cuales se analizan los principios constitucionales que son vulnerados por las sanciones de multa de los Sub-códigos 18.1 y 18.3 del TUO del RISPAC, modificado por el Decreto Supremo $\mathrm{N}^{\circ}$ 009-2013-PRODUCE, además se revisan elementos jurídicos y jurisdiccionales sobre las sanciones en el sector pesquero, y finalmente se presenta un balance jurídico sobre el sistema de control difuso.

En el segundo capítulo, se analiza el funcionamiento del PAS en el sector pesquero describiendo las causas que generan una sanción, la forma de aplicación de los Sub-códigos 18.1 y 18.3 del TUO del RISPAC, modificado por el Decreto Supremo $\mathrm{N}^{\circ}$ 009-2013-PRODUCE y sus criterios, para finalizar analizando la dificultad que genera esta sanción en el sector pesquero y el Estado peruano.

El tercer capítulo se orienta a comprender el impacto que genera la sanción en el sector pesquero a nivel económico y, además, de generar la negativa por parte de los empresarios dedicados a esta actividad al pago de la multa.

El cuarto capítulo establece las acciones que presenta el sector empresarial pesquero ante la imposición de sanción de la multa, pues como se ha señalado las personas naturales y jurídicas (empresas) dedicadas a este rubro prefieren apelar en vía administrativa y solicitar la nulidad de la Resoluciones Directorales sancionatorias hasta llegar a instancias jurisdiccionales, finalmente se presenta al Control Difuso Administrativo como una alternativa de resolución de estas controversias buscando generar celeridad en los procesos administrativos en beneficio de los empresarios y del Estado peruano, así como la aplicación de una mejor técnica legislativa en la creación de normas de carácter reglamentario, tales como decretos supremos, resoluciones ministeriales, entre otros.

El capítulo quinto, presenta las conclusiones de esta investigación en la que se advierten falta de técnica legislativa en la elaboración del Decreto Supremo $\mathrm{N}^{\circ}$ 009-2013-PRODUCE, específicamente en la modificación de las fórmulas de los Sub-códigos 18.1 y 18.3 del cuadro de sanciones del TUO del 
RISPAC; y, el fin del Control Difuso Administrativo, con la emisión de la STC $\mathrm{N}^{\circ}$ 4293-2012-PA/TC, por parte del Tribunal Constitucional. Asimismo, en el último capítulo se desarrollan las recomendaciones en materia jurídica respecto al caso estudiado, donde se recomienda la emisión de un nuevo Reglamento de Inspecciones y Sanciones Pesqueras y Acuícolas, siguiendo los alcances de técnica legislativa, establecidos en Ley $\mathrm{N}^{\circ}$ 26889, Ley Marco para la Producción y Sistematización Legislativa y su reglamento aprobado por el Decreto Supremo $\mathrm{N}^{\circ}$ 008-2006-JUS, que corrija las fórmulas de los Sub-códigos 18.1 y 18.3 del cuadro de sanciones del TUO del RISPAC; y, la habilitación por parte del Tribunal Constitucional del Control Difuso Administrativo, para que los tribunales u órganos colegiados de la Administración Publica como es el Consejo de Apelación de Sanciones (CONAS) pueda inaplicar normas legales infraconstitucionales.

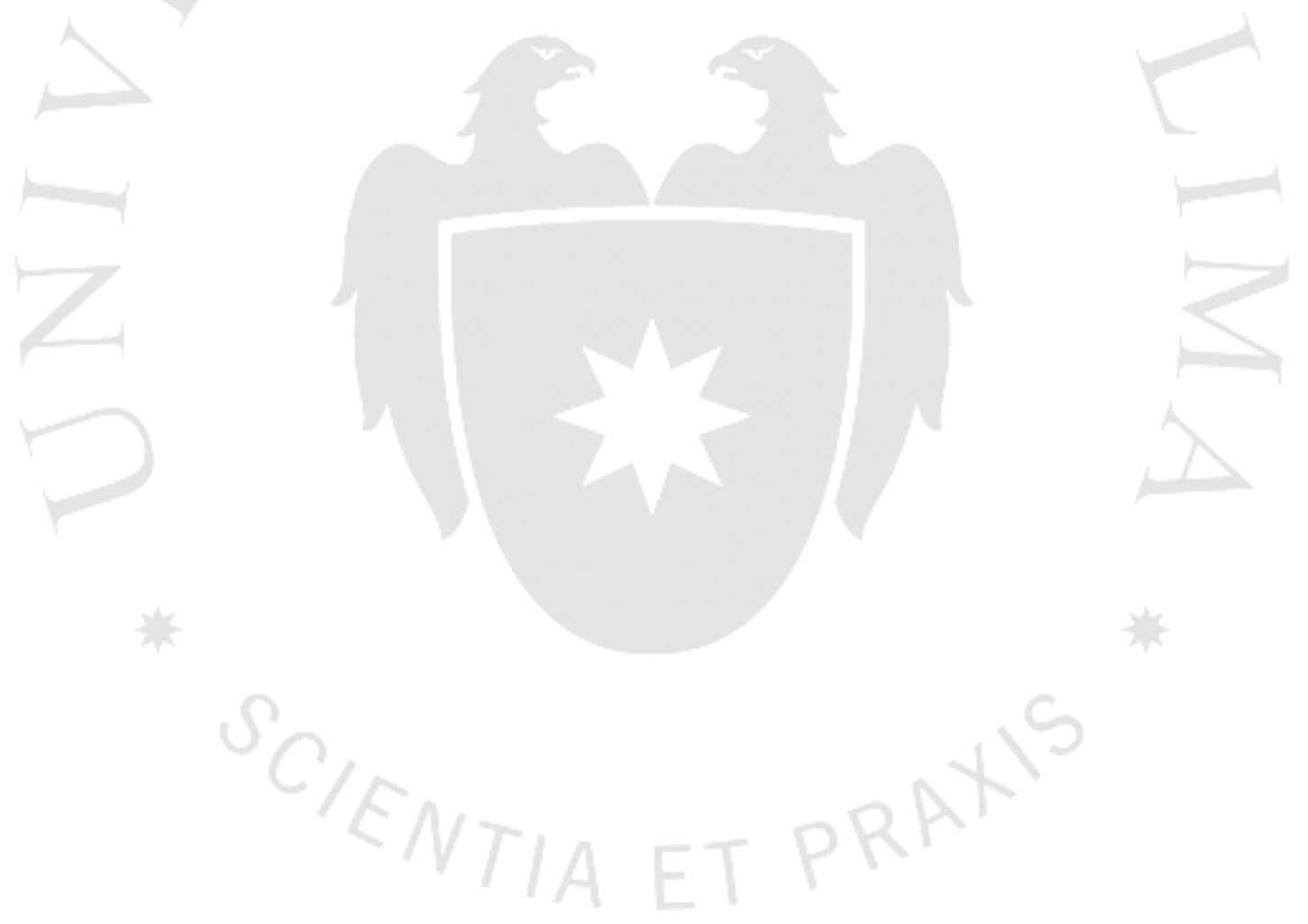




\section{CAPITULO I: ASPECTOS CONCEPTUALES}

Para comprender los aspectos y principios jurídicos asociados a los procedimientos sancionadores que enfrentan las personas naturales y jurídicas en su calidad de administrados que operan en el sector pesquero en nuestro país es necesario analizar los principios de libertad de empresa, de razonabilidad y no confiscatoriedad, contemplados en la Constitución Política, piedra angular de nuestro sistema normativo. En las siguientes páginas se presenta un balance sobre la literatura en cuestión de las más recientes reflexiones sobre el caso.

Además, se presentan los elementos jurídicos y jurisdiccionales sobre las sanciones en materia pesquera y una propuesta alternativa del empleo del Control Difuso Administrativo, para generar celeridad en la resolución de los conflictos originados entre órgano sancionador y los administrados.

\subsection{Principios constitucionales vulnerados por las fórmulas de las sanciones aplicadas en el procedimiento administrativo sancionador}

- Principio de Libertad de Empresa: La Constitución Política en el artículo 59 señala que:

El Estado estimula la creación de riqueza y garantiza la libertad de trabajo y la libertad de empresa, comercio e industria. El ejercicio de estas libertades no debe ser lesivo a la moral, ni a la salud, ni a la seguridad pública. El Estado brinda oportunidades de superación a los sectores que sufren cualquier desigualdad; en tal sentido, promueven las pequeñas empresas en todas sus modalidades.

Bajo este numeral y con la aplicación de una economía social de mercado se genera como consecuencia una mayor actividad empresarial al fomentar la inversión extranjera y dinamizar el mercado laboral, tan limitado en nuestro medio (Chamané 2011).

El adecuado funcionamiento de este modelo económico solo es factible en países donde se promueva: 
[...] la libertad de empresa, derecho de propiedad, libertad de iniciativa privada, libertad de contratación, libre competencia y protección al consumidor, son garantías que forman parte del núcleo duro de la Constitución Económica y son lo que podríamos llamar los principios y derechos fundamentales del sistema constitucional económico. (Gutiérrez 2013, p. 38)

No obstante, el libre mercado no es solo respeto de las libertades empresariales, sino que principalmente es protección al consumidor, siendo este último su límite por naturaleza, y no solo beneficia al consumidor sino también a los propios empresarios quienes sin la libertad de empresa vería reducidas sus posibilidades de ingresar al mercado, por lo que este límite representa una protección contra los propios empresarios.

La lectura de este artículo a prima facie, sugiere que el Estado se encuentra obligado a estimular la creación de la riqueza, cuando en principio debe ser el mercado el llamado a encargarse de dicha tarea, siendo el Estado un regulador que debe corregir las imperfecciones del mercado y eliminar las posibles distorsiones que se produzcan, muchas de las cuales son de responsabilidad del propio Estado (Guzmán 2015).

De acuerdo a Guzmán (2015), la Constitución Política no establece la forma o medios en los que el Estado debe promover la creación de la riqueza, dado que no señala textualmente si el estímulo es directo o solo consiste en remover los obstáculos que impiden el desarrollo empresarial adecuado, especialmente, los obstáculos burocráticos generados por el propio Estado. Sobre este aspecto, Walter Gutiérrez opina que:

Para el orden público económico consagrado en la Constitución, el centro de la actividad económica recae en la empresa privada; de esta manera, se deja en manos de los particulares la organización y dirección del proceso económico. Son ellos los encargados de crear riqueza, siendo el Estado responsable de generar las condiciones para que el mercado funcione. Por consiguiente, no es tarea del Estado participar directamente en la actividad económica, su función es más bien reguladora. (Gutiérrez 2013, p. 38)

Este autor agrega que una interpretación progresista de la norma podría llevarnos a pensar que dicho estímulo es directo, requiriendo de una intervención directa del Estado en la actividad económica (Gutiérrez 2013) 
Las libertades empresariales son derechos constitucionales y fundamentales para una economía social de mercado, toda vez que la libertad de empresa se entiende como "el mecanismo a través del cual el ser humano hace efectivo su deseo de procurar satisfacer las necesidades de los demás a través de la actividad empresarial y con un legítimo afán de lucro.” (Cusi 2014)

La doctrina afirma que la libertad de empresa es la concreción de la iniciativa privada entendida como actividad empresarial, libertad de contratación, libertad de trabajo, entre otras, de cara a generar bienes o servicios deseados, contribuyendo con el mercado. Por ello, actualmente, es imposible pensar en mercado sin empresa o en empresa sin mercado.

Por su parte, el Tribunal Constitucional peruano, ha definido la libertad de empresa como:

[...] la facultad de poder elegir la organización y efectuar el desarrollo de una unidad de producción de bienes o prestación de servicios para satisfacer la demanda de los consumidores o usuarios. La libertad de empresa tiene como marco una actuación económica autodeterminativa, lo cual implica que el modelo económico social de mercado será el fundamento de su actuación y, simultáneamente, le impondrá límites a su accionar. Consecuentemente, dicha libertad debe ser ejercida con sujeción a la ley - siendo sus limitaciones básicas aquellas que derivan de la seguridad, la higiene, la moralidad o la preservación del medio ambiente-, y su ejercicio deberá respeta los diversos derechos de carácter socio-económico que la Constitución reconoce (STC N ${ }^{\circ}$ 07320-2005PA/TC.F.J.53)

\section{- Contenido Constitucional de la Libertad de Empresa:}

Según la Sentencia del Expediente Nº018-2003-AI/TC:

[..] la libertad de empresa es el derecho de las personas a elegir libremente la actividad ocupacional o profesional que desee o prefiera desempeñar, disfrutando su rendimiento económico y satisfacción espiritual. Ello es así, en razón que el Estado garantiza la libertad de empresa, comercio e industria y porque la libertad de empresa se incardina dentro de la libertad de trabajo, el cual, a su vez es una manifestación del derecho fundamental al trabajo. (Sentencia del Expediente $\mathrm{N}^{\circ}$ 0018-2003-AI/TC) 
Asimismo, la libertad de Empresa, se encuentra caracterizada por cuatro tipos de libertades, las mismas que fueron desarrolladas por el Tribunal Constitucional en el fundamento 13 de la STC $\mathrm{N}^{\circ}$ 03330-2004-AA/TC, en el fundamento 6 de la STC $\mathrm{N}^{\circ}$ 00003-2006-PI/TC y en el fundamento 15 de la STC N 01405-2010-PA/TC, basándose en los trabajos de Bassolls (1989) y Kresalja (2004), dichas libertades son:

- Libertad de creación de empresa: Libertad para emprender actividades económicas en el sentido de libre fundación de empresas y concurrencia al mercado.

- Libertad de organización: Libre elección de objeto, nombre, domicilio, tipo de empresa o de sociedad mercantil, facultades a los administradores, políticas de precios, créditos y seguros, contratación de personal, política publicitaria, entre otros.

- Libertad de Competencia: Libertad de decisión de los actores del mercado bajo un marco jurídico normativo claro, esta libertad de decisión o elección es tanto para el proveedor y el consumidor.

- Libertad de cierre de empresa: Es la libertad para quien haya creado una empresa, de disponer el cierre o cesación de las actividades de la misma cuando lo considere más oportuno.

\section{- Libertad de Empresa y Libertad de Trabajo}

Estos derechos deben diferenciarse y tratarse de manera separada, puesto que el primero se vincula de manera directa con la prestación de servicios realizados por una persona en relación de subordinación, poseyendo un componente negativo (libertad de no ser obligado a desempeñar o dejar de desempeñar un trabajo de manera indebida) y otro positivo (elegir el trabajo que uno prefiera y ejercerlo libremente dentro del marco establecido por el ordenamiento jurídico, incluido el establecido por el empleador). Según Raúl Chamané:

El Tribunal Constitucional ha estado confundiendo los derechos de Libertad de Trabajo y Libertad de Empresa en reiterada jurisprudencia, señalando que uno implica al otro, sin tomar en cuenta la naturaleza subordinada del trabajo al que alude la norma constitucional; en igual sentido se pronuncia cierto sector de la doctrina, al señalar que la libertad de trabajo es un derecho accesorio al de la libertad de empresa. (2013:533) 


\section{- Límites a las libertades empresariales}

La Constitución señala que el ejercicio de las libertades de creación de empresa, organización, competencia y cierre de empresa, no debe ser lesivo a la moral, ni a la salud o seguridad públicas. Sin embargo, Guzmán (2015) crítica que se tenga como uno de los límites a la moral, pues es un concepto demasiado subjetivo y admite diversas interpretaciones, debiéndose recurrir al concepto de reserva de ley, contenido en la legislación comparada y desarrollada por la jurisprudencia y doctrina nacionales, por el cual los derechos fundamentales solo pueden ser limitados por la ley, siendo obvio que la libertad de empresa es un derecho fundamental, en uso del artículo $3^{\circ}$ de la Constitución Política:

Artículo 3.- La enumeración de los derechos establecidos en este capítulo no excluye los demás que la Constitución garantiza, no otros de naturaleza análoga o que se fundan en la dignidad del hombre, o en los principios de soberanía del pueblo, del Estado democrático de derecho y de la forma republicana de gobierno." (Constitución Política del Perú 1993).

En conclusión, llevando lo mencionado párrafos precedentes al PAS y teniendo en cuenta que bajo los alcances de la Constitución Política, el Estado garantiza la creación de la riqueza y la libertad de empresa, aplicada bajo el modelo de una economía social de mercado, este último en su rol de policía (fiscalizador y sancionador) debe imponer sanciones a los administrados proporcionales al incumplimiento calificado como infracción, con el objeto de corregir las conductas negativas de los actores en el presente caso del sector pesquero.

- Principio de Razonabilidad: Este principio se encuentra establecido en el numeral 3) del artículo $246^{\circ}$ del Texto Único Ordenado de la Ley del Procedimiento Administrativo General $N^{\circ}$ 27444, aprobado por el Decreto Supremo $N^{\circ}$ 006-2017-JUS (TUO de la Ley $\mathrm{N}^{\circ}$ 27444), sobre el particular el profesor Juan Carlos Morón Urbina precisa que nuestro Tribunal Constitucional tiene establecido, que el principio de razonabilidad o proporcionalidad es consustancial al Estado Social y Democrático de Derecho, y está configurado en la Constitución Política en sus artículos $3^{\circ}, 43^{\circ}$, y plasmado expresamente en su artículo $200^{\circ}$, último párrafo. Asimismo, precisa que, por el principio de razonabilidad, los actos de gravamen deben adoptarse dentro los límites de la 
facultad atribuida y manteniendo la debida proporción entre los medios a emplear y los fines públicos que deba tutelar a fin que responda a lo estrictamente necesario para la satisfacción de su cometido, de otro lado precisa que el principio de razonabilidad conlleva al cumplimiento de tres dimensiones:

- Sub principio de adecuación: Tenemos que la medida sancionadora debe ser idónea para lograr el fin u objetivo previsto por el legislador cuando le autorizo su empleo.

- Sub principio de necesidad: hace lugar a la regla de la aplicación moderada de las sanciones, esto es que deben ser impuestas en la forma y medida estrictamente necesarias para que cumpla su finalidad.

- Sub principio de proporcionalidad: consiste en que la sanción guarda una relación razonable - ventajas y desventajas- con el fin que se procura alcanzar.

De otro lado, Vergaray y Gómez (2009), precisan que de acuerdo a la versión del numeral 3) del artículo $230^{\circ}$ de la Ley $\mathrm{N}^{\circ} 27444$, modificada, por el Decreto Legislativo $\mathrm{N}^{\circ} 1029$, versión muy parecida a la establecida por el reciente Decreto Legislativo $\mathrm{N}^{\circ} 1272$, las sanciones deben ser proporcionales al incumplimiento calificado como infracción, debiendo observar los siguientes criterios:

i) La gravedad del daño al interés público y/o bien jurídico protegido: al aplicar este criterio, la autoridad administrativa debe realizar un análisis en abstracto de los efectos de la conducta infractora en relación con la relevancia o trascendencia del bien jurídico o interés afecto.

ii) El perjuicio económico causado deberá ser considerado como una circunstancia agravante a aplicarse en aquellos casos en los que se verifique que el daño real ocasionado supera el beneficio ilícito percibido por el infractor, para ello se deberá considerar: a) el daño objetivo, en el que se encuentran el daño emergente y el lucro cesante; y, b) el daño subjetivo en el que se encuentran el daño moral y el daño a la persona.

iii) La repetición y/o continuidad en la comisión de la infracción, al momento de establecer el monto de la sanción a imponerse, la autoridad administrativa deberá considerar la reincidencia o reinterancia, como un factor que determina el incremento de las sanciones. Lo anterior, considerado que el objeto de la imposición de las sanciones es evitar que continúe resultando conveniente para que el administrado incurra en una determinada conducta ilícita. 
iv) Las circunstancias de la comisión de la infracción constituirá un factor agravante o atenuante dependiendo de cada caso en particular

v) El beneficio ilegalmente obtenido, para determinar la sanción base a la que se le aplicaran los criterios agravantes o atenuantes que permitan incrementarla o disminuirla, será necesario considerar tanto el beneficio ilegalmente obtenido como la probabilidad de detención

vi) la existencia o no de intencionalidad en la conducta del infractor dado que para que se configure la infracción administrativa basta que haya culpa o imprudencia; en aquellos casos en los que se verifique la existencia de dolo ello será considerado como un agravante que habilitará a la autoridad administrativa a incrementar el monto de la sanción. (2009: 415-417)

En ese sentido, llegamos a la conclusión que para la elaboración de las multas tiene que verificarse la razonabilidad y proporcionalidad de la sanción, asimismo para su imposición debe evaluarse la gravedad del daño al interés público y/o bien jurídico protegido, el perjuicio económico causado, la reincidencia, las circunstancias de la comisión de la infracción, el beneficio ilegalmente obtenido y la existencia o no de intencionalidad, para que no se emita sanciones excesivas y desproporcionales, respecto del monto impuesto.

Asimismo Morón (2010) precisa que la proscripción del exceso de punición entendido como aquel vicio de nulidad del acto administrativo incurrido cuando la sanción impuesta a un administrado no guarda proporcionalidad con el objetivo de la norma represiva que sustento el dictado del precepto como una emisión del acto administrativo sancionador, en ese sentido, el exceso de punición es un típico ejemplo de falta de proporcionalidad entre el contenido del acto sancionador y su finalidad que es un requisito para la validez del acto administrativo.

- Principio de no confiscatoridad: La parte final del segundo párrafo del artículo $74^{\circ}$ de la Constitución Política, precisa que ningún tributo puede tener carácter confiscatorio. Al respecto, Gutiérrez menciona que "la Constitución Política vigente contiene una limitación del ejercicio del poder tributario del Estado, con el rango de principio de la tributación y con la denominación de principio de no confiscatoriedad" (2013:941), al respecto la jurisprudencia Constitucional establece, en el párrafo 24 de la STC N ${ }^{\circ} 4227$ 2005-PA/TC, que de acuerdo a lo resuelto en la STC N²302-2003-AA/TC, el Tribunal Constitucional estableció que para acreditar la confiscatoriedad en cada caso, es necesario 
probar la afectación real del patrimonio empresarial de la persona jurídica y "que no podría ser de otra manera cuando se alega afectación exorbitante a la propiedad privada" (stc $\mathrm{n}^{\circ}$ 4227_2005:PA/TC). Asimismo la STC $\mathrm{N}^{\circ}$ 0041-2004-AI/TC, precisa en sus párrafos 56, 57, 61 y 62, que el principio de no confiscatoriedad informa y limita el ejercicio de la potestad tributaria estatal garantizando que la Ley Tributaria no puede afectar irrazonable y desproporcionalmente la esfera patrimonial de las personas, asimismo precisa una diferenciación entre la confiscatoriedad cuantitativa y cualitativa, siendo la primera la que se basa en el monto o suma descomunal, que afectaría la propiedad privada, y la segunda la que produce una sustracción ilegitima de la propiedad por vulneración de otros principios tributarios, sin que interese el monto de los sustraído, pudiendo ser en muchos casos perfectamente soportable.

La jurisprudencia constitucional, ha llevado el principio de no confiscatoridad al procedimiento sancionador, específicamente a las sanciones de multa, las cuales siempre se traducen en una cuantía que deben asumir los administrados a través de su patrimonio al incurrir en una infracción; es así que la STC N 1492-2003-AA/TC, sobre la acción de amparo presentada por la IMPORTADORA TONY TOYS S.R.L., sustentando su defensa entre otros fundamentos, en que la multa impuesta tiene un efecto confiscatorio, por lo desproporcional que resulta respecto de su capacidad económica real (confiscatoriedad cuantitativa), sobre el particular el Tribunal Constitucional, menciono en el párrafo 27, que:

En cuando a la alegada confiscatoriedad de la multa impuesta, este colegiado considera que, en principio las multas -a diferencia de los tributos- no son susceptibles de declaración de confiscatoriedad, salvo que se constate una extrema irracionalidad, ya sea por su cuantía o su falta de adecuación a la gravedad de la infracción. (STC N ${ }^{\circ}$ 14922003-AA/TC)

En ese sentido, centrándonos en el caso en concreto, si introducimos la no confiscatoriedad al Procedimiento Administrativo Sancionador (PAS) en materia pesquera, concluimos en que, el citado principio desarrollado en la Carta Magna, aplica como límite de la potestad sancionadora, garantizando que la normatividad de la materia no afecte irrazonable y desproporcionalmente la esfera patrimonial de las personas naturales y jurídicas (empresas) en su calidad de operadores del sector pesquero. 


\subsection{Elementos jurídicos, funcionales y de competencia sobre las sanciones en Pesquería}

De acuerdo a lo dispuesto en el artículo $66^{\circ}$ de la Constitución Política los recursos naturales renovables, son patrimonio de la Nación y el Estado es soberano en su aprovechamiento.

Asimismo, debemos precisar que los recursos naturales renovables son aquellos que después de haber pasado por el proceso de explotación no se agotan, en el presente trabajo nos enfocaremos en los recursos hidrobiológicos los cuales son organismos de origen animal o vegetal que desarrollan todo o gran parte de su ciclo vital en ambientes acuáticos y que posteriormente directa o indirectamente son aprovechados por el ser humano, generando en la mayoría de los casos utilidades económicas a los actores privados del sector, lo cual se traduce en un incremento del Producto Bruto Interno del Perú.

El Estado, para la preservación de los recursos hidrobiológicos en cumplimiento de lo dispuesto de los artículos $66^{\circ}$ y $67^{\circ}$ de la Constitución Política aplica una política mediante, la cual promueve el uso sostenible de los mencionados recursos. Es preciso mencionar que la Ley $\mathrm{N}^{\circ}$ 26821, Ley Orgánica de Aprovechamiento Sostenible de los Recursos Naturales, estable en sus dos primeros artículos, que los regímenes de aprovechamiento sostenible de los recursos naturales, en tanto constituyen patrimonio de la Nación, las condiciones y modalidades de otorgamiento a particulares, se realizan cumpliendo el mandato contenido en los mencionados artículos de la Carta Magna, asimismo la promoción, regulación tal como indica la Ley 26821

Artículo 20.- La presente Ley Orgánica tiene como objetivo promover y regular el aprovechamiento sostenible de los recursos naturales, renovables y no renovables, estableciendo un marco adecuado para el fomento a la inversión, procurando un equilibrio dinámico entre el crecimiento económico, la conservación de los recursos naturales y del ambiente y el desarrollo integral de la persona humana.

En ese sentido, en aplicación de la Ley $N^{\circ}$ 27658, Ley Marco de Modernización de la Gestión del Estado; bajo las facultades otorgadas por el Congreso de la Republica, mediante Ley $\mathrm{N}^{\circ}$ 29157, el Poder Ejecutivo a través del Decreto Legislativo $\mathrm{N}^{\circ} 1047$, aprobó la Ley de Organización y Funciones del Ministerio de la Producción, para que sea competente entre otras actividades en pesquería y acuicultura, asimismo se precisa que el 
citado Ministerio ostenta competencia de "manera exclusiva en materia de ordenamiento pesquero, pesquería industrial, acuicultura de mayor escala y ordenamiento de productos fiscalizados y competencia de manera compartida con los Gobiernos Regionales y Gobiernos Locales, según corresponda." (RM №163-2017-PRODUCE)

De otro lado, es preciso mencionar que el numeral 5.2 del artículo $5^{\circ}$ del Decreto Legislativo $\mathrm{N}^{\circ} 1047$, establece que el Ministerio de la Producción ostenta como funciones rectoras y especificas dictar normas y lineamientos técnicos para ejecución y supervisión de las políticas, la gestión de los recursos del sector, así como para el otorgamiento, reconocimiento de derechos, la sanción, fiscalización y ejecución coactiva.

De acuerdo a lo mencionado precedentemente llegamos a la conclusión que el Ministerio de la Producción, es el sector que cuenta con la competencia y tiene como funciones, regular el manejo integral y la explotación racional de los recursos hidrobiológicos, bajo el lineamiento rector que la actividad pesquera es de interés nacional, ostentando la potestad sancionadora frente a los actores del sector pesquero o administrados cuando infrinjan o vulneren la normatividad de la materia.

Asimismo, debemos precisar que, de acuerdo a lo previsto en el Principio de Legalidad, instaurado en el numeral 1) del artículo $246^{\circ}$ del TUO de la Ley $\mathrm{N}^{\circ} 27444$, solo por norma con rango de Ley, cabe atribuir a las entidades la potestad sancionadora, en el presente caso, el Ministerio de la Producción la ostenta de acuerdo a lo previsto en el numeral 5.2 del artículo $5^{\circ}$ del Decreto Legislativo $\mathrm{N}^{\circ}$ 1047. Sobre el particular, Guzmán (2010) menciona que:

Por la potestad sancionadora, la Administración se encuentra facultada para sancionar a los administrados por la comisión de infracciones establecidas por el ordenamiento jurídico. Es preciso indicar que por primera vez se establece en la Ley del Procedimiento Administrativo General una regulación expresa de la potestad sancionadora, aplicándosele incluso garantías que inicialmente se consideraban propias del derecho penal. $\mathrm{Y}$ es que, no todo acto contrario a las normas debe ser sancionado penalmente, dado el carácter subsidiario de dicha rama del derecho, que opera siempre como última ratio, como ya lo hemos explicado. En consecuencia, el ordenamiento debe establecer la posibilidad de la aplicación de sanciones administrativas, que funcionen también como mecanismos de control social, pero de una manera pero de una manera que es relativamente más benigna. (Guzmán 2010:653-654) 
De acuerdo a lo previsto en el artículo $230^{\circ}$ de la Ley $\mathrm{N}^{\circ} 27444$, modificada por el Decreto Legislativo $\mathrm{N}^{\circ} 1272$, en concordancia con lo dispuesto en el artículo $246^{\circ}$ del TUO de la Ley $N^{\circ} 27444$, la potestad sancionadora de todas las entidades del Estado está regida por los principios de: Legalidad, Debido Procedimiento, Razonabilidad, Irretroactividad, Concurso de Infracciones, Continuación de Infracción, Causalidad, Licitud, Culpabilidad y Non Bis In Ídem, los cuales de acuerdo a lo mencionado Morón (2010), cumplen una triple función: la fundante (preceder a la existencia de las reglas mismas de la potestad sancionadora), la interpretativa (servir de criterio hermenéutico para absolver cualquier duda sobre el sentido y alcance de las reglas de la potestad sancionadores), y la integradora (servir de fuente de integración para las lagunas jurídicas que se puedan identificar en aplicación de las normas sancionadoras).

Finalmente, respecto de los principios especiales de la potestad sancionadora establecidos para el PAS, de acuerdo a lo dispuesto en el numeral 245.2 del artículo $245^{\circ}$ del TUO de la Ley $\mathrm{N}^{\circ}$ 27444, serán de aplicación supletoria a todos los procedimientos establecidos en las leyes especiales, los que deben observarlos necesariamente, asimismo precisa que los procedimientos especiales no pueden imponer condiciones menos favorables a los administrados que los previstos en el Capítulo III del Título IV, del mencionado TUO.

De otro lado, de acuerdo a lo previsto en los artículos $252^{\circ}$ y $253^{\circ}$ del TUO de la Ley $\mathrm{N}^{\circ} 27444$, para el ejercicio de la potestad sancionadora se requiere obligatoriamente haber seguido el PAS, caracterizado por diferenciar en su estructura entre la autoridad que conduce la fase instructora y la que decide la aplicación de la sanción, para lo cual el Ministerio de la Producción mediante el artículo $1^{\circ}$ del Decreto Supremo No $002-2017$ PRODUCE, que aprobó el nuevo Reglamento de Organización y Funciones (ROF), el cual se adecua a la nueva estructura del PAS ordenando por el Decreto Legislativo $\mathrm{N}^{\circ}$ 1272, encargándole de conducir la etapa de instrucción de acuerdo a lo previsto el literal 1) del artículo $87^{\circ}$ del citado ROF, a la Dirección de Supervisión y Fiscalización y de resolver en primera instancia el PAS a la Dirección de Sanciones (DS-PA) en virtud de lo tipificado en los literales a), b) y e) del artículo $89^{\circ}$ del precitado $\mathrm{ROF}$, asimismo en cumplimiento de lo previsto por el sub-numeral 1.2, del numeral 1 del artículo IV del Título Preliminar del TUO de la Ley $\mathrm{N}^{\circ} 27444$, en concordancia con lo dispuesto el literal a) del artículo $126^{\circ}$ del mencionado ROF, el Consejo de Apelación de Sanciones 
(CONAS), resuelve los recursos de apelación interpuestos contra las Resoluciones Directorales sancionadoras, en el presente caso en materia pesquera.

En ese sentido, llegamos a la conclusión que la DS-PA ostenta en primera instancia la potestad sancionada del Ministerio de la Producción en materia pesquera, en atención a ello el artículo $77^{\circ}$ de la Ley General de Pesca, promulgada por el Decreto Ley $\mathrm{N}^{\circ}$ 25977, precisa que constituye infracción toda acción u omisión que contravenga o incumpla alguna de las normas contenidas en la presente Ley, su Reglamento o demás disposiciones sobre la materia, infracciones que serán sancionadas con: a) Multa, b) Suspensión de la concesión, autorización, permiso o licencia, c) Decomiso; y, d) Cancelación definitiva de la concesión, autorización, permiso o licencia, de acuerdo a lo tipificado en el artículo $78^{\circ}$ del citado cuerpo normativo y se impondrán a las personas naturales o jurídicas que infrinjan las disposiciones establecidas.

\subsection{El control Difuso}

- Sistemas Constitucionales de Control: Control Difuso y Control Concentrado

Teniendo en cuenta la importancia de la Constitución Política dentro del Estado y la colectividad en que vivimos, es necesaria para un manejo eficiente la existencia y aplicación de mecanismos que hagan respectar el cumplimiento de los mandatos contenidos en el citado cuerpo normativo, esto es el control constitucional sobre el marco normativo en sus diferentes dispositivos legales emitidos por órganos competentes para el ordenamiento social y económico de un país.

La Constitución Política de 1993, siguiendo los pasos de su antecesora de 1979, para realizar el control constitucional del marco normativo peruano ha optado por dos sistemas de control de la constitucionalidad de nuestro ordenamiento legal, el Sistema de Control Concentrado de origen Austriaco; y, el Sistema de Control Difuso o Judicial Review de origen Americano, estos dos sistemas cumplen la función de realizar un control constitucional de las normas infra constitucionales, es decir las emitidas sin respetar los preceptos contenidos en la actual Carta Magna. 
Sobre el particular, Vergara Gotelli, en su voto singular (FJ 7) realizado en la Sentencia del Pleno del Tribunal Constitucional (STC) $N^{\circ}$ 00014-2009PI/TC, precisa que nuestro país bajo lo establecido por la actual Carta Magna ha asumido un sistema dual de control constitucional, en el cual coexisten: i) El Sistema de Control de Difuso; y, ii) El Sistema de Control Concentrando.

Es así que el Control Difuso, como antecedente fue recogido en el artículo $236^{\circ}$ de la Constitución Política de 1979 y actualmente se encuentra establecido en el artículo $138^{\circ}$ de la actual Carta Magna, otorgándose este control al Poder Judicial como poder exclusivo capaz de resolver controversias, de otro lado de acuerdo a lo establecido en el artículo $201^{\circ}$ del mismo cuerpo normativo, se le otorgo al Tribunal Constitucional.

El Control Difuso nace en 1803, a nivel federal en los Estados Unidos de Norteamérica con la emisión de la sentencia que resolvió el famoso caso Marbury vs Madison, que estableció la facultad de los tribunales de juzgar la conformidad de una norma de rango legal con la Constitución e implicar aquellas leyes que la contravengan.

Sin embargo es preciso mencionar que si bien es cierto que la Corte Suprema Federal Norteamericana fue la primera institución con atribuciones jurisdiccionales a nivel mundial, ello no fue algo que se gestó de la noche a la mañana, sino que prosiguió el derrotero iniciado en Inglaterra, por el common law británico.

El Espinoza-Saldaña (2009), menciona que como es de conocimiento, en la Inglaterra de antes de siglo XVII el common law, la normativa no recogía por escrito, prevalecía sobre las normas formales o statutes. Estas últimas eran más bien vistas como normas particulares o excepcionales en relación con el derecho consuetudinario previamente establecido. Este fue el sustento del célebre fallo emitido por el entonces juez Coke en 1610 en el Bonham case. El common law estaba por encima de cualquier otra normativa y por ende, sus intérpretes y aplicadores más cualificados, los jueces podían tomar decisiones que descalificaban todo lo contrario a ese common law, aun cuando fuese leyes del Parlamento o incluso órdenes del Rey. 
Sin embargo, muy conocido es también que lo señalado por el juez Coke en el Bonham case, fue en Inglaterra dejado de lado luego del triunfo de la denominada Revolución Gloriosa de 1688. Ahora bien, mientras el devenir histórico iba por otros derroteros como los de la soberanía del Parlamento. En los Estados Unidos fue la postura que tomo mayor predicamento

De otro lado sobre el control constitucional, Guzmán (2005) menciona que:

[...] la Constitución como norma jurídica goza de la llamada supremacía, puesto que aquella es la norma más importante de las existentes al interior de un Estado, principio que permite que la constitución sea la norma matriz del ordenamiento jurídico nacional. Este principio proviene de distintos orígenes, el primero como ya ha sido mencionado es el caso Marbury vs Madison, en el cual se determinó no solo que la Constitución era norma suprema, sino además que los jueces podían inaplicar la norma legal al caso concreto cuando encontraban que esta estaba en desacuerdo con la norma constitucional, no obstante que dicha prerrogativa no se encontraba señalada en la Constitución de los Estados Unidos. (Guzmán 2005)

Dicha facultad se denominó judicial review; conforma lo que se conoce como control difuso de constitucionalidad y apareció como un contrapeso al poder que poseería el Congreso en mérito al principio de legalidad y el sometimiento al mismo por parte del estado en su conjunto.

Guzmán (2004) considera que existen diferencias en los procesos europeos y latinoamericanos, pues señala que:

En el caso europeo la evolución fue diferente, puesto que se determinó la existencia de un ente especializado que tutelara la constitucionalidad de las leyes, de tal forma que los jueces no puedan implicar por decisión propia una norma de rango legal. La aparición de dicho mecanismo se dio con la Constitución austriaca de 1920, modificada en 1929, luego se propago a la mayor parte de Europa y de ahí a Latinoamérica. El citado ente que sería denominado en general Tribunal Constitucional, posee la facultad de derogar la norma en cuestión, con evidentes efectos erga omnes, a través del uso del denominado Control Concentrado de constitucionalidad. (Guzmán 2004) 


\section{- Control Difuso en el Perú}

Un primer acercamiento del Control Difuso en el Perú, se dio con la publicación y vigencia del Código Civil de 1936, el cual en su artículo XXII del Título Preliminar estableció: "Articulo XXII: Cuando hay incompatibilidad entre una disposición constitucional y una legal se prefiere la primera”. De acuerdo al profesor Aníbal Quiroga León, esta disposición, poco entendida y poco estudiada, tuvo como antecedente el artículo $148^{\circ}$ del Proyecto de la Constitución de 1925.

Sobre el particular, con relación a los alcances artículo XXII del Título Preliminar del Código Civil de 1936, Arias-Koga (2015) en su trabajo de tesis denominado "El Difuso Administrativo y sus Implicancias en el estado Constitucional de Derecho", precisa que el contenido del citado artículo que integro al ordenamiento jurídico peruano el mecanismo del Control Difuso solo abarco el ámbito civil y no a todo los ámbitos jurídicos, esto se debió a que no estaba constitucionalizado, por lo cual paso de ser percibido y no tuvo el impacto con el que actualmente cuenta el mencionado mecanismo de control.

El artículo $8^{\circ}$ de la Ley Orgánica del Poder Judicial de 1963, señala: Artículo $8^{\circ}$ : Cuando los Jueces o Tribunales, al conocer cualquiera clase de juicios, encuentren que hay incompatibilidad entre una disposición constitucional y una legal, preferirán la primera. Si no fueran apeladas las sentencias de Primera Instancia en que se aplique este precepto, se elevaran en consulta a la Primera Sala de la Corte Suprema. Las sentencias de Segunda Instancia se elevaran en consulta a la Primera Sala de la Corte Suprema, si no se interpusiere recurso de nulidad.

De igual forma, esta previsión tampoco tuvo gran auge ni fue práctica usual en sede judicial. Sin embargo, nadie señaló o discutió la posibilidad de que tal principio y tal potestad estuviera fuera del sistema judicial o del Poder Judicial.

Como ya hemos mencionado en el subcapítulo anterior el Control Difuso se instauro constitucionalmente por primera vez en el Perú en la Carta Magna de 1979, estableciéndose el citado mecanismo de control en el artículo $236^{\circ}$, para luego tipificarse finalmente en la Constitución aún vigente de 1993, en su artículo $138^{\circ}$. 
De otro lado, es preciso mencionar que el citado mecanismo de control constitucional, ha sido también recogido en el artículo VI del Título Preliminar del Código Procesal Constitucional, promulgado por la Ley $\mathrm{N}^{\circ} 28237$, estableciendo los siguientes alcances:

Artículo Vl.- Control Difuso e Interpretación Constitucional: Cuando exista incompatibilidad entre una norma constitucional y otra de inferior jerarquía, el Juez debe preferir la primera, siempre que ello sea relevante para resolver la controversia y no sea posible obtener una interpretación conforme a la Constitución.

Los Jueces no pueden dejar de aplicar una norma cuya constitucionalidad haya sido confirmada en un proceso de inconstitucionalidad o en un proceso de acción popular.

Los Jueces interpretan y aplican las leyes o toda norma con rango de ley y los reglamentos según los preceptos y principios constitucionales, conforme a la interpretación de los mismos que resulte de las resoluciones dictadas por el Tribunal Constitucional.

Respecto del artículo VI del Título Preliminar del Código Procesal Constitucional, el profesor Carlos Mesía Ramírez, amparándose en nuestra actual Carta Magna y en la jurisprudencia del Tribunal Constitucional, menciona que el Control Difuso de la constitucionalidad de las normas constituye un poder-deber del juez al que el artículo $138^{\circ}$ de la Constitución Política, habilita el mecanismo para preservar el principio de supremacía constitucional y, en general, el principio de jerarquía de las normas, enunciado en el artículo $51^{\circ}$ de nuestra norma fundamental.

El Control Difuso es un acto complejo en la medida en que significa preferir la aplicación de una norma cuya validez, en principio resulta beneficiada de la presunción de legitimidad de las normas del Estado. Por ello su ejercicio no es un acto simple, requiriéndose, para que él sea válido la verificación de cada caso de los siguientes presupuestos: a) Que en el proceso constitucional, el objeto de impugnación sea un acto que constituya la aplicación de una norma considerada inconstitucional, b) Que la norma a implicarse tenga una relación directa, principal e indisoluble con la resolución del caso, es decir que ella sea relevante en la resolución de la controversia; y, c) Que la norma a implicarse resulte evidentemente incompatible con la Constitución, aun luego de haberse acudido 
a interpretarla de conformidad con la Constitución Política (STC Exp. $\mathrm{N}^{\circ}$ 01124-2001-AA-ff.jj.13.a, 13.b y 13.c).

Finalmente, para la aplicación del Control Difuso en el Perú, se deberá tomar en cuenta lo previsto en el artículo $14^{\circ}$ del Texto Único Ordenado de la Ley Orgánica del Poder Judicial, aprobado por el Decreto Supremo No 017-93-JUS, el cual provee que:

i) Cuando los Magistrados al momento de fallar el fondo de la cuestión de su competencia, en cualquier clase de proceso o especialidad, encuentren que hay incompatibilidad en su interpretación, de una disposición constitucional y una con rango de ley, resuelven la causa con arreglo a la primera.

ii) Las sentencias así expedidas son elevadas en consulta a la Sala Constitucional y Social de la Corte Suprema, si no fueran impugnadas. Lo son igualmente las sentencias en segunda instancia en las que se aplique este mismo precepto, aun cuando contra éstas no quepa recurso de casación.

iii) En todos estos casos los magistrados se limitan a declarar la inaplicación de la norma legal por incompatibilidad constitucional, para el caso concreto, sin afectar su vigencia, la que es controlada en la forma y modo que la Constitución establece.

iv) Cuando se trata de normas de inferior jerarquía, rige el mismo principio, no requiriéndose la elevación en consulta, sin perjuicio del proceso por acción popular. (Decreto Supremo No 017-93-JUS)

\section{- Control Difuso Administrativo}

Como ya hemos mencionado precedentemente el Control Difuso, de acuerdo a lo dispuesto por el artículo $138^{\circ}$ de la Constitución Política, es atribuido solo a los órganos jurisdiccionales, bajo el precepto de que al existir incompatibilidad entre una norma constitucional y una norma legal los jueces prefieren la primera, inaplicado las leyes o normas con rango de ley al ser consideradas infraconstitucionales, respecto de esta premisa, a inicios del siglo XX, vía jurisprudencial nació la pregunta sobre si la Administración Publica, podría inaplicar una ley por ser inconstitucional; de acuerdo a lo precisado por el profesor Víctor Sebastián Baca Oneto, la discusión en torno a la admisibilidad del control difuso en sede administrativa se planteó por primera vez con la emisión de la Resolución N$^{\circ}$ 0259-2001/TDC-INDECOPI, dictada el 16 de abril 
de 2001, bajo el Exp. N 111-2000/CRP-ODI-CCPL, en este caso el Tribunal del Instituto Nacional de Defensa de la Competencia y de la Protección de la Propiedad Intelectual (INDECOPI), se negó por mayoría a inaplicar un decreto de urgencia cuya inconstitucionalidad había sido alegada, al considerase que dicha pretensión excedía de sus competencias.

Es preciso mencionar INDECOPI señaló que:

pretender que un tribunal administrativo como esta Sala aplique el control de constitucionalidad expresamente atribuido por la propia Constitución a los jueces en el acápite correspondiente al Poder Judicial importaría arrogarse atribuciones, desconocer el principio de legalidad -toda vez que no existe norma de desarrollo constitucional que así lo establezca- y subvertir el Estado de Derecho (Resolución N 0259-2001/TDC-INDECOPI)

Sin embargo el Abogado Alfredo Bullard González, en su calidad de integrante del Tribunal del INDECOPI, emitió su voto en minoría, mediante el cual fundamento que el control difuso se trata de una potestad implícita a los tribunales administrativos, cuya labor se asemeja a la realizada por los jueces.

Posteriormente, al más alto nivel jerárquico, el Tribunal Constitucional, con la emisión de la STC $\mathrm{N}^{\circ}$ 007-2001-AI-TC, en su etapa de negación del Control Difuso Administrativo, rechaza totalmente la posibilidad de que la Administración Publica en este caso a través de la Municipalidad de San Juan de Lurigancho pueda inaplicar normas infraconstitucionales, exponiendo en su tercer fundamento lo siguiente:

En lo que respecta al primer extremo, el Tribunal estima que la municipalidad emplazada ha incurrido en un evidente exceso, pues la facultad de declarar inaplicables normas jurídicas, conforme a lo que establece el artículo $138^{\circ}$ de nuestra Constitución Política, sólo se encuentra reservada para aquellos órganos constitucionales que, como el Poder Judicial, el Jurado Nacional de Elecciones o el propio Tribunal Constitucional, ejercen funciones jurisdiccionales en las materias que les corresponden y no para los órganos de naturaleza o competencias eminentemente administrativas. Por consiguiente, si bien resulta inobjetable que cualquier poder público u organismo descentralizado tiene facultad para interpretar la Constitución y, por ende, para aplicarla en los casos que corresponda, no pueden, en cambio, arrogarse una potestad, como la de 
declarar inaplicables normas infraconstitucionales, que la Constitución no les ha conferido de modo expreso e inobjetable. (STC N 007-2001-AI-TC.f.j.03)

Posteriormente, Quiroga (2010) precisa que tres (03) años más adelante el mismo Tribunal Constitucional, en su calidad de órgano de control de la Constitución y máximo intérprete de la misma, el día 14 de noviembre de 2005, con la expedición de la STC $\mathrm{N}^{\circ}$ 3741-2004-AA/TC, sobre la causa de amparo constitucional presentado por el señor Ramón Hernando Salazar Yarleque, dio un vuelco rotundo, fijando como precedente vinculante la interpretación extensiva del artículo $138^{\circ}$ de la Constitución en vigencia, señalando que también correspondería esta facultad-potestad a los órganos colegiados y tribunales administrativos (Administración Publica), precisando que:

[...] si bien el artículo $138^{\circ}$ de la Constitución reconoce a los jueces la potestad para realizar el control difuso, de ahí no se deriva que dicha potestad para realizar el control difuso, corresponda únicamente a los jueces, ni tampoco que el control difuso se realice únicamente dentro de marco de un proceso judicial.

Para entender mejor la resolución que dio origen al Control Difuso Administrativo, es necesario tomar en cuenta lo publicado por la Editorial Gaceta Jurídica, en su ejemplar $\mathrm{N}^{\circ} 48$, denominado Gaceta Constitucional, en el cual realiza un análisis de la STC N³741-2004-AA-TC (11.10.2006) y su Aclaratoria (13.10.2006), extirpando los principales extractos, bajo la noción de tres conceptos:

\section{i) La Constitución como límite de las actuaciones de la administración}

- La Administración Publica tiene el deber de preferir la Constitución e inaplicar una disposición infraconstitucional (STC $\mathrm{N}^{\circ}$ 3741-2004-AA-TC.f.j.50).

Todo tribunal u órgano colegiado de la Administración Publica tiene la facultad y el deber de preferir la Constitución e inaplicar una disposición infracosntitucional que vulnera manifiestamente, bien por la forma, bien por el fondo, de conformidad con los artículos $38^{\circ}, 51^{\circ}$ y $138^{\circ}$ de la Constitución.

- La Actuación de la Administración Publica se encuentra sometida a la Constitución (STC N 3741-2004-AA-TC.f.j.6).

La Administración Publica [...] al igual que los poderes del Estado y los órganos constitucionales, se encuentra sometida, en primer lugar, a la Constitución de 
manera directa $y$, en segundo lugar, al principio de legalidad, de conformidad con el artículo $51^{\circ}$ de la Constitución, de modo tal que la legitimidad de los actos administrativos no viene determinada por el respecto a la ley, sino antes bien por su vinculación a la Constitución.

- Aplicación de una ley inconstitucional implica vaciar el contenido del principio de supremacía de la Constitución (STC N 3741-2004-AA-TC.f.j.16).

La aplicación de una ley inconstitucional por parte de la Administración Publica implica vaciar de contenido el principio de supremacía de la Constitución, así como el de su fuerza normativa, pues se estaría otorgando primacía al principio de legalidad en detrimento de la Supremacía Jurídica de la Constitución.

\section{ii) El órgano competente para ejercitar el control difuso}

- Tribunales administrativos tienen el deber constitucional de realizar el Control Difuso (STC N³741-2004-AA-TC.f.j.7).

La Administración Publica, a través de sus tribunales administrativos o de sus órganos colegiados, no solo tiene la facultad de hacer cumplir la Constitución, sino también el deber constitucional de realizar el control difuso de las normas que sustentan los actos administrativos y que son contrarias a la Constitución o la interpretación que de ella haya realizado el Tribunal Constitucional.

- Tribunales que imparten justicia administrativa con carácter nacional están facultados para ejercer Control Difuso (STC $\mathrm{N}^{\circ}$ 3741-2004-AA-TC. Aclaratoria.f.j.4).

Que, si bien los funcionarios de la Administración Publica se encuentran sometidos al principio de legalidad, ello no es incompatible con lo que se ha señalado en el fundamento 50 de la sentencia Exp $\mathrm{N}^{\circ} 3741-2004-\mathrm{AA} / \mathrm{TC}$, esto es, que (...) todo tribunal u órgano colegiado, de la Administración Pública tiene la facultad y el deber de preferir la Constitución e implicar una disposición infraconstitucional que la vulnere manifiestamente (...). Precisamente con respecto a este extremo de la sentencia mencionada, el Tribunal Constitucional estima necesario precisar que los tribunales administrativos u órganos colegiados a los que se hace referencia en dicho fundamento son aquellos tribunales $\mathrm{u}$ órganos colegiados administrativos que imparten justicia administrativa con carácter nacional, adscritos al Poder Ejecutivo y que tengan por finalidad la declaración de derechos fundamentales de los administrados. (STC $N^{\circ}$ 37412004-AA-TC. Aclaratoria.f.j.4) 


\section{iii) Derechos fundamentales como límites del principio de legalidad.}

- Control Difuso guarda relación con los derechos al debido proceso y a la tutela procesal del administrado (STC $\mathbf{N}^{\circ}$ 3741-2004-AA-TC.f.j.11)

Si antes la eficacia y el respecto de los derechos fundamentales se realizaban en el ámbito de la ley, en el Estado Constitucional, la legitimidad de las leyes se evalúa en función de su conformidad con la Constitución y los derechos fundamentales que ella reconoce. Por eso mismo es pertinente señalar que el derecho y el deber de los tribunales administrativos y órganos colegiados de preferir la Constitución a la Ley, es de realizar el control difuso, forma parte del contenido constitucional protegido del derecho fundamental del administrado al debido proceso y a la tutela procesal ante los tribunales administrativos.

- Control Difuso guarda relación con los derechos al debido proceso y a la tutela procesal del administrado (STC $\mathbf{N}^{\circ}$ 3741-2004-AA-TC.f.j.11)

Si antes la eficacia y el respecto de los derechos fundamentales se realizaban en el ámbito de la ley, en el Estado Constitucional, la legitimidad de las leyes se evalúa en función de su conformidad con la Constitución y los derechos fundamentales que ella reconoce. Por eso mismo es pertinente señalar que el derecho y el deber de los tribunales administrativos y órganos colegiados de preferir la Constitución a la Ley, es de realizar el control difuso, forma parte del contenido constitucional protegido del derecho fundamental del administrado al debido proceso y a la tutela procesal ante los tribunales administrativos.

En ese sentido podemos concluir, en que todo tribunal u órgano colegiado adscrito al Poder Judicial y de alcance nacional, con la emisión de la STC $\mathrm{N}^{\circ}$ 3741-2004-AA-TC y su Aclaratoria, podría utilizar el mecanismo de Control Difuso Administrativo, inaplicando normas legales, que resulten infraconstitucionales, de acuerdo a lo previsto por los artículos $38^{\circ}, 51^{\circ}$ y $138^{\circ}$ de la Constitución Política, situación que se presentó en cinco (05) tribunales administrativos de alcance general, los cuales ejercieron en sus colegiados el citado mecanismo de control constitucional durante aproximadamente ocho (08) años.

Finalmente con fecha 18 de marzo de 2014, mediante la STC $\mathrm{N}^{\circ} 4293$ 2012-PA/TC, el supremo intérprete de la Constitución Política, puso fin al 
Control Difuso Administrativo, dejando sin efecto los alcances de la STC $\mathrm{N}^{\circ}$ 3741-2004-AA-TC y su Aclaratoria, sentencia del tribunal que emanó producto de la demanda de amparo presentado por el Consorcio Requena contra la Primera Sala del Tribunal de Contrataciones del Organismo Supervisor de las Contrataciones del Estado (OSCE), solicitando la nulidad de la Resolución $\mathrm{N}^{\circ}$ 170-2012-TC-S1.

Retomando los alcances de $\mathrm{STC} \mathrm{N}^{\circ}$ 4293-2012-PA/TC, respecto al fin del Control Difuso Administrativo, debemos precisar que en los fundamentos $30 \mathrm{y}$ 31 de la citada sentencia, se cuestiona la forma en que se emitió el precedente vinculante Salazar Yarleque, contenido en la STC N 3741-2004-PA/TC, en el sentido que se emitió incumpliendo las reglas fijadas por la STC N 00024-2003$\mathrm{AI} / \mathrm{TC}$, para el establecimiento de un precedente vinculante.

Por su parte, Ochoa (2014), precisa que en el fundamento 33 de la sentencia que puso fin al precedente Salazar Yarleque, el Supremo Tribunal señala tres (03) objeciones relevantes:

- La primera objeción: El control difuso es una atribución exclusiva del Poder Judicial. En el peor de los casos esta atribución solo se puede extender a quienes ejercen función jurisdiccional.

- La segunda objeción: Es que la sentencia para revocar el precedente del caso Salazar Yarleque afirma que la Ley Orgánica del Poder Judicial ha establecido la consulta como instrumento de control de la actividad de los jueces cuando apliquen el control difuso en la resolución de procesos judiciales. Como este instrumento no está previsto para el Control Difuso Administrativo las resoluciones así emitidas por los tribunales administrativos quedarían firmes en la vía administrativa y exenta de control.

- La tercera objeción: Para revocar el precedente sostiene que afecta el sistema de control dual de jurisdicción constitucional establecido en la Constitución y reservado para el Poder Judicial y/o Tribunal Constitucional y afecta el principio de separación de poderes, dado que se permite que un tribunal administrativo que forma parte del Poder Ejecutivo, controle las normas dictadas por el Poder Legislativo, lo que, conforme a la Constitución, solo puede ocurrir en un proceso jurisdiccional y no en uno de naturaleza administrativa. (Ochoa 2014:35) 
- De otro lado de acuerdo a Rivas (2010), debemos mencionar que durante la práctica del Control Difuso Administrativo, se presentó entre otros los siguientes problemas:

- Falta de capacitación de los funcionarios públicos: La especulación respecto de las dificultades que plantea la falta de preparación de los funcionarios públicos en materia constitucional a fin de que estos se encuentren capacitados para examinar la inconstitucionalidad de las leyes y su consecuente inaplicación en sede administrativa ha sido confirmada en la práctica.

- Ausencia de publicidad de las resoluciones: Se ha constatado que los tribunales administrativos de competencia nacional no poseen un sistema de publicidad de las sentencias en las que han aplicado el control difuso. Ello no solo impide la frecuencia de su utilización, así como su adecuada puesta en práctica, sino también la cantidad de solicitudes que presentan los administrados y las consecuentes razones de su procedencia o improcedencia.

- Falta de independencia de los tribunales administrativos: Como ya se ha mencionado, esta configura una de las principales objeciones teóricas para la implementación del control difuso en sedea administrativa.

El principal problema que tuvo la aplicación del Control Difuso en Sede Administrativa, se generó desde la emisión de la STC N³741-2004-AA-TC y su Aclaratoria, en el sentido que el Tribunal Constitucional al otorgar a la Administración Publica, este mecanismo tan complejo y delicado de control de constitucionalidad de las normas, no habilito un procedimiento de consulta o revisión, como si lo tenía el Órgano Jurisdiccional, establecido en el artículo $14^{\circ}$ de la Ley Orgánica del Poder Judicial, aprobada por el Decreto Supremo Nº 017 93-JUS, el cual indica que las sentencias expedidas en un proceso donde se haya hecho uso de este control constitucional, serán elevadas en consulta a la Sala Constitucional y Social de la Corte Suprema.

El propósito del artículo citado en el párrafo precedente radica en proteger el principio de Seguridad Jurídica, al realizar un control sobre las sentencias que implicaron normas al emplear el mecanismo del Control Difuso, con el objeto de generar uniformidad en la jurisprudencia al concentrar su revisión en un órgano superior. 


\section{CAPITULO II: EL PROCEDIMIENTO ADMINISTRATIVO SANCIONADOR DE EMPRESAS PESQUERAS}

\subsection{Causales de sanción de multa}

Para comprender las causales de sanción debe remitirse al artículo $1^{\circ}$ de la Ley General de Pesca, promulgada por el Decreto Ley $N^{\circ} 25977$, la cual tiene por objeto normar la actividad pesquera con el fin de promover su desarrollo sostenido como fuente de alimentación, empleo e ingresos y de asegurar un aprovechamiento responsable de los recursos hidrobiológicos, optimizando los beneficios económicos, en armonía con la preservación del medio ambiente y la conservación de la biodiversidad, de otro lado cabe precisar que mediante el artículo $126^{\circ}$ del Reglamento de la Ley General de Pesca, aprobado por el Decreto Supremo N ${ }^{\circ}$ 012-2001-PE, se establece que:

Constituye infracción administrativa toda acción u omisión que como tal se encuentre tipificada en la Ley, su Reglamento, reglamentos de ordenamiento pesquero y de acuicultura y demás disposiciones que se dicten sobre la materia.

Siguientemente, de acuerdo al numeral 136.1) del artículo $136^{\circ}$ del Reglamento de la Ley General de Pesca, precisa que conforme a lo previsto en el artículo $78^{\circ}$ :

Artículo 78.- Obligaciones de los titulares de las actividades pesqueras y acuícolas

Los titulares de las actividades pesqueras y acuícolas son responsables de los efluentes, emisiones, ruidos y disposición de desechos que generen o que se produzcan como resultado de los procesos efectuados en sus instalaciones, de los daños a la salud o seguridad de las personas, de efectos adversos sobre los ecosistemas o sobre la cantidad o calidad de los recursos naturales en general y de los recursos hidrobiológicos en particular, así como de los efectos o impactos resultantes de sus actividades. Por lo tanto, están obligados a ejecutar de manera permanente planes de manejo ambiental y, en consecuencia, a realizar las acciones necesarias para prevenir o revertir en forma progresiva, según sea el caso, la generación y el impacto negativo de las mismas, a través de la implementación de prácticas de prevención de la contaminación y procesos con tecnologías limpias, prácticas de reuso, reciclaje, tratamiento y disposición final. 
Asimismo, están obligados a adoptar medidas destinadas a la conservación de los recursos hidrobiológicos y de los ecosistemas que les sirven de sustento.

La infracción a la legislación pesquera se sanciona, indistinta o conjuntamente, con multa, suspensión, decomiso definitivo o cancelación de la autorización, licencia, concesión o permiso.

Conforme a lo previsto en el artículo $137^{\circ}$ del precitado Reglamento , se entiende que la imposición de multas posee dos aspectos relevantes: i) las multas impuestas tienen como valor de referencia la Unidad Impositiva Tributaria (UIT) -que se encuentre vigente en el momento de cometida la infracción-; y, ii) la cuantía de las multas se determina considerando el perjuicio causado a los recursos hidrobiológicos y el beneficio ilegalmente obtenido, sin embargo en las cuantías o las fórmulas de sanción de multa, no se contempla en la Ley General de Pesca ni en su Reglamento, determinados criterios que se consideran pertinentes indicar, como la evaluación de los capitales sociales, las rentas o ingresos anuales declarados por las personas naturales o jurídicas (empresas), en su calidad de actores del sector pesquero, con el objeto respectar lo dispuesto por el artículo $74^{\circ}$ de la Constitución Política, llevado al PAS por la jurisprudencia del Tribunal Constitucional, en el sentido que las sanciones de multas no pueden tener carácter confiscatorio al afectar el patrimonio de los administrados en su calidad de infractores, a su vez, debe contemplarse evaluar factores como: i) la probabilidad de detección, ii) la reincidencia, iii) los agravantes; y, iv) los atenuantes; factores que se vienen incorporando al Proyecto de Decreto Supremo que aprueba el nuevo Reglamento de Fiscalización y Sanción de las Actividades Pesqueras, el cual actualmente se encuentra pre-publicado, mediante la Resolución Ministerial N 163-2017-PRODUCE, desde el 10 de abril de 2017, bajo el Mecanismo de Participación, para recibir comentarios, opiniones y sugerencias.

\subsection{El tipo del numeral 18), la falta de Técnica Legislativa aplicada a la} fórmula de la sanción de multa y el caso EMPRESA CANTABRIA S.A.

El Reglamento de la Ley General de Pesca, aprobado por el Decreto Supremo No 012 2001-PE, en su artículo $134^{\circ}$ establece 127 infracciones, de las cuales, en el presente 
trabajo de acuerdo a sus características de tipo y sanción, tocaremos la tipificada actualmente en el numeral 18), la cual de acuerdo a su ultima modificatoria consiste en que la embarcación pesquera supervisada y fiscalizada por la Dirección de Supervisión y Fiscalización, mediante el Sistema de Seguimiento Satelital (SISESAT):

[...] presente códigos de manipulación, distorsión o señales de posición congeladas emitidos desde los equipos del Sistema de Seguimiento Satelital - SISESAT, operando fuera de puertos y fondeaderos; así como impedir por cualquier medio o acto la transmisión de los equipos del SISESAT, de manera tal que se interrumpa la señal por un intervalo mayor de una hora y treinta (30) minutos, operando fuera de puertos y fondeaderos.

La infracción citada en el párrafo precedente se incorporó a la normatividad pesquera inicialmente en el numeral 21) del artículo $134^{\circ}$ del Reglamento de la Ley General de Pesca, aprobado por el Decreto Supremo No 012-2001-PE, la misma que posteriormente fue modificada y reubicado el tipo en el numeral 18) del mencionado artículo, con el Decreto Supremo N ${ }^{\circ}$ 015-2007-PRODUCE, modificándose varias veces con la entrada en vigencia de los Decretos Supremos Nros. 005-2008-PRODUCE, 016-2011PRODUCE, 009-2013-PRODUCE y finalmente con el Decreto Supremo Nº 001-2014PRODUCE.

En ese sentido, cuando una embarcación pesquera de acuerdo a la última modificatoria del numeral 18) del Reglamento de la Ley General, durante su faena de pesca: i) presenta códigos de manipulación, distorsión emitidos desde los equipos del SISESAT, operando fuera de puertos y fondeaderos, ii) presenta señales de posición congeladas emitidos desde los equipos del SISESAT, operando fuera de puertos y fondeaderos, iii) impide por cualquier medio o acto la transmisión de los equipos del SISESAT, de manera tal que se interrumpa la señal por un intervalo mayor de una hora y treinta (30) minutos, operando fuera de puertos y fondeaderos; incurre en infracción, la cual es detectada por el Área de Monitoreo del SISESAT de la Dirección de Supervisión y Fiscalización, la misma que ante la conducta desplegada, emite tres (03) documentos denominados Informe Técnico, Informe SISESAT, y Diagrama de Desplazamiento, los cuales de acuerdo a lo dispuesto en el artículo $38^{\circ}$ del TUO del RISPAC, aprobado por el Decreto Supremo $N^{\circ}$ 019-2011-PRODUCE, en su calidad de norma especial que regula el procedimiento sancionador en materia pesquera, constituyen medios probatorios de la comisión de los hechos por parte del presunto infractor. 
Posteriormente, la DS-PA con los medios probatorios adjuntos al Informe de Instrucción emitido y alcanzado por el Área de Instrucción de la Dirección de Supervisión y Fiscalización, después de una evaluación de la presunta infracción a la norma pesquera, en el caso en concreto a lo tipificado por el numeral 18) del artículo $134^{\circ}$ del Reglamento de la Ley General de Pesca, modificado por el Decreto Supremo No 001-2014PRODUCE, impone la sanción de acuerdo a los tres (03) Sub-códigos de infracción, del Código 18, del cuadro de sanciones señalado por el artículo $47^{\circ}$ del TUO del RISPAC, modificado por el Decreto Supremo Nº09-2013-PRODUCE.

Las sanciones que se aplican por infringir lo tipificado por el numeral 18) del artículo $134^{\circ}$ del Reglamento de la Ley General de Pesca, como ya mencionamos en el párrafo precedente son tres (03) y se imponen teniendo en cuenta la conducta en la que incurrió el administrado que ostentaba el manejo o posesión de la embarcación pesquera al momento de ocurridos los hechos materia de infracción, de acuerdo al siguiente cuadro:

Tabla 2.1.

Tabla Resumen de Sanciones

\begin{tabular}{|c|c|c|c|c|}
\hline Código & Sub Código & Infracción & \multicolumn{2}{|c|}{ Sanción } \\
\hline 18 & 18.1 & $\begin{array}{l}\text { Presentar códigos de } \\
\text { manipulación o distorsión } \\
\text { desde los equipos del } \\
\text { SISESAT }\end{array}$ & Multa & $\begin{array}{l}8 \times \text { (Capacidad de } \\
\text { bodega en m3) en } \\
\text { UIT }\end{array}$ \\
\hline & 18.2 & \begin{tabular}{lrr} 
Presentar & señales de \\
posición & \multicolumn{2}{c}{ congeladas } \\
emitidas & desde & equipos \\
SISESAT & &
\end{tabular} & Cancelación & $\begin{array}{l}\text { Del permiso de } \\
\text { pesca }\end{array}$ \\
\hline & 18.3 & $\begin{array}{l}\text { Impedir por cualquier medio } \\
\text { o acto la trasmisión de los } \\
\text { equipos de SISESAT de } \\
\text { manera tal que se interrumpa } \\
\text { la señal por un intervalo }\end{array}$ & Multa & $\begin{array}{l}8 \times(\text { Capacidad de } \\
\text { bodega en m3) en } \\
\text { UIT }\end{array}$ \\
\hline
\end{tabular}

Fuente: Artículo $134^{\circ}$ del Reglamento de la Ley General de Pesca. Elaboración: Propia

La problemática radica cuando se aplican a los administrados que tienen el manejo de las embarcaciones pesqueras al momento de ocurridos los hechos materia de infracción, las sanciones establecidas en los Sub-códigos 18.1 y 18.3, puesto que la fórmula de multa para ambos casos es de $8 \times$ (Capacidad de bodega en m3) en UIT, la cual al calcularse es excesiva y desproporcional. 
Veamos un ejemplo de la aplicación de la misma, de acuerdo a la Resolución Directoral $\mathrm{N}^{\circ}$ 3351-2016-PRODUCE/DGS, emitida por la Dirección General de Sanciones (hoy DS-PA), con fecha 20 de mayo de 2016.

El artículo $1^{\circ}$ de la citada resolución directoral, sancionó a la empresa PESQUERA CANTABRIA S.A., en calidad de propietaria de la embarcación pesquera ATLANTICO I de matrícula CO-5300-PM, con una multa de 3,193.04 UIT, al incurrir en la infracción prevista en el numeral 18) del artículo $134^{\circ}$ del Reglamento de la Ley General de Pesca, modificado por el Decreto Supremo Nº09-2013-PRODUCE, por interrumpir las señales de posicionamiento satelital, por un intervalo mayor a dos (02) horas, operando fuera de puertos y fondeaderos, el 29 de noviembre de 2013, aplicándosele la sanción establecida en el Sub-código 18.3 del cuadro de sanciones del TUO del RISPAC, modificado por el Decreto Supremo N 009-2013-PRODUCE, en virtud al siguiente detalle.

De acuerdo al Portal Virtual del Ministerio de la Producción, la embarcación pesquera ATLANTICO I, cuenta con una capacidad de bodega neta en metros cúbicos (m3) de 399.130, en tal sentido al aplicársele la sanción de multa establecida en el Subcódigo 18.3, se calcularía de la siguiente formula: 8 x $(399.130)=3,193.04$ UIT, la cual al multiplicarse por el valor asignado por el Ministerio de Economía y Finanzas a la referida unidad (S/ 3,700 soles), mediante Decreto Supremo N 264-2012-EF, arrojaría la cantidad de S/ 11'814,248 (ONCE MILLONES OCHOCIENTOS CATORCE MIL DOSCIENTOS CUARENTA Y OCHO CON 00/100 SOLES).

En ese sentido respecto de la multa calculada mediante la fórmula aprobada por el Decreto Supremo N 009-2013-PRODUCE, en el caso de los Sub-códigos 18.1 y 18.3 del cuadro de sanciones del TUO del RISPAC, modificado por el Decreto Supremo $\mathrm{N}^{\circ}$ 009-2013-PRODUCE, consideramos que es excesiva y desproporcional, la cual atenta contra el principio de razonabilidad, establecido tanto en el numeral 3) del artículo $246^{\circ}$ del TUO de la Ley $\mathrm{N}^{\circ} 27444$, como en los artículos $3^{\circ}, 43^{\circ}$ y $200^{\circ}$ de la Constitución Política.

De otro lado, mencionaremos que los montos de las sanciones de multas arrojados por el cálculo de las fórmulas de los Sub-códigos 18.1 y 18.3, del mencionado TUO, al ser elevados y desproporcionales devendrían en confiscatorios al afectar el patrimonio de las personas naturales o jurídicas (empresas) del sector pesquero, incumpliendo los 
dispuesto en la parte final del segundo párrafo del artículo $74^{\circ}$ de la Carta Magna, teniendo en cuenta que el principio de no confiscatoriedad, de acuerdo a lo precisado por la jurisprudencia constitucional, es de aplicación a las multas del procedimiento sancionador, cuando se constate una extrema irracionalidad en la cuantía.

A su vez es preciso, analizar en el presente capitulo la técnica legislativa aplicada en la elaboración del Decreto Supremo Nº 009-2013-PRODUCE, el cual introdujo a la normatividad pesquera, las fórmulas para establecer las sanciones de multa, tipificadas en los en los Sub-códigos 18.1 y 18.3 del cuadro de sanciones del TUO del RISPAC, modificado por el Decreto Supremo N 009-2013-PRODUCE; sobre el particular de acuerdo a la Guía Técnica Legislativa para la Elaboración de Proyectos Normativos de las Entidades del Poder Ejecutivo, aprobada por Resolución Directoral Nº 007-2016JUS/DGDOJ, debemos mencionar que el Poder Ejecutivo tiene la potestad de reglamentar las leyes o complementar lo dispuesto en una ley, asimismo también precisa tomar en cuenta que las entidades y organismos públicos que integran el Poder Ejecutivo también se encuentran facultadas para emitir normatividad de carácter general.

El artículo $1^{\circ}$ de la Ley $\mathrm{N}^{\circ}$ 26889, Ley Marco para la Producción y Sistematización Legislativa, en concordancia con lo dispuesto en el artículo I del Título Preliminar de su Reglamento, aprobado por el Decreto Supremo Nº08-2006-JUS, establecen que los citados cuerpos normativos contienen los lineamientos para la elaboración, denominación y publicación de dispositivos legales, como anteproyectos de ley y proyecto de decretos legislativos, decretos de urgencia y decretos supremos.

El numeral 1.2 del artículo $1^{\circ}$ del Reglamento de la Ley Marco para la Producción y Sistematización Legislativa, aprobado por el Decreto Supremo N 008-2006-JUS, establece que los Decretos Supremos están integrados por: i) Titulo de la disposición, ii) Parte Expositiva o exposición de motivos, iii) Análisis costo beneficio, solo en el caso de Decretos Supremos que versen sobre materias económicas y financieras, iv) Análisis de impacto de la vigencia de la norma en la legislación nacional; y, v) Formula normativa, que incluye una parte considerativa y una parte expositiva; sobre el particular; si bien es cierto para la emisión del Decreto Supremo Nº09-2013-PRODUCE, se contó con un texto de exposición de motivos, el citado documento solo en su décimo primer párrafo expuso de manera somera y ligera, que se modificará el artículo $134^{\circ}$ del Reglamento de la Ley General de Pesca, respecto de la extracción de recursos hidrobiológicos y el presentar velocidades de pesca, en zonas que hayan sido suspendidas, adecuando por 
consiguiente el cuadro de sanciones del TUO del RISPAC, aprobado por el Decreto Supremo $N^{\circ}$ 019-2011-PRODUCE, sin realizar mayor análisis económico sobre las fórmulas de las sanciones de multas establecidas en los Sub-códigos 18.1 y 18.3, sin aplicar lo dispuesto en el artículo $3^{\circ}$ del Reglamento de la Ley Marco para la Producción y Sistematización Legislativa, el cual precisa que el estudio costo beneficio sirve como método de análisis para conocer en términos cuantitativos, los impactos y efectos que tiene una propuesta normativa sobre diversas variables que afectan entre otros a los actores del sector, en el caso en concreto del presente trabajo de investigación, al patrimonio de los propietarios o poseedores de las embarcaciones pesqueras, al imponérseles multas exorbitantes y desproporcionales.

Finalmente, se puede señalar en el presente capítulo, de acuerdo a lo mencionado precedentemente, como mecanismos de solución de la problemática advertida, respecto de la aplicación de las sanciones de multa previstas en los Sub-códigos 18.1 y 18.3, del cuadro de sanciones del TUO del RISPAC, modificadas por el Decreto Supremo Nº092013-PRODUCE: i) la emisión de un nuevo Reglamento de Inspecciones y Sanciones Pesqueras y Acuícolas o la modificatoria del ya existente; o, ii) la aplicación del Control Difuso Administrativo, por parte del CONAS, en su calidad de tribunal u órgano colegiado de la Administración Publica.

\subsection{Las dificultades entre la aplicación de la norma y la realidad pesquera}

Según los datos recogidos por el Instituto Nacional de Estadística e Informática (INEI) para el 2017, la actividad productiva pesquera en la escena nacional es muy importante, en el sentido que la producción nacional hasta el mes de febrero del mencionado año creció $0,74 \%$, cuyo resultado se sustentó en la evaluación favorable de varios sectores como telecomunicaciones, minería e hidrocarburos, pesca, entre otros, a su vez el crecimiento de la actividad productiva también se sustenta en el aumento del volumen de exportaciones en $32,4 \%$, entre las que se destacan el cobre, oro, derivados del petróleo, harina y aceite de pescado. Hasta el mes de febrero del presente, el índice de producción pesquera experimento un crecimiento de $30,59 \%$ con respecto al año anterior.

A nivel de producción pesquera expresada en nuevos soles el INEI señala que el total de producción marítima de 2016 se obtuvieron S/ 3053,690,437. 
Figura 2.1.

Producción pesquera expresada en Nuevos Soles 2016

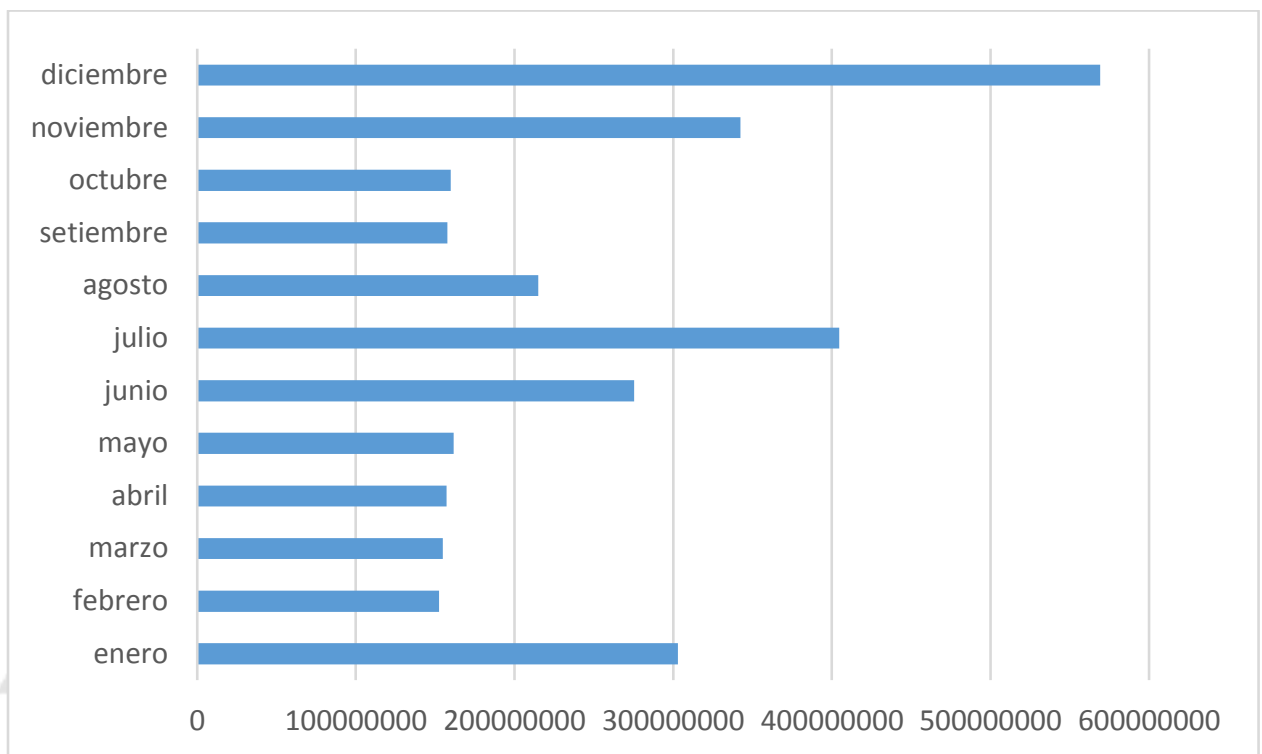

Fuente: INEI. Elaboración: propia

A su vez, según la Sociedad Nacional de Pesquería (2016), el sector pesquero otorga un importante número de divisas al país y se ubica dentro de las cuatro actividades económicas con mayores ingresos, de acuerdo al Banco Central de Reserva del Perú, ya que hasta el año 2016, el sector representó aproximadamente el $7 \%$ de las exportaciones a nivel nacional, siendo el Perú a nivel internacional el responsable del $25-30 \%$ de la producción mundial de harina y aceite de pescado.

Según Alfaro (2010), en el Perú se han realizado importantes avances para asegurar la sostenibilidad de algunos recursos, como el establecimiento a nivel nacional del tipo y tamaño de artes de pesca, el tamaño mínimo de las especies, épocas de veda y la cuota global para la anchoveta, hasta el año 2010 -año de la publicación del libro de Alfaro Perú, país marítimo consideraba que se requiere aún desarrollar mayores dispositivos para que se lleve a cabo la actividad pesquera sostenible. A su vez, menciona que en el Perú se tiene la visión de orientar la pesca de la anchoveta (en mayor volumen) al CDH (consumo humano directo) desde hace más de 50 años, cuyos resultados desde una perspectiva nutricional fueron muy buenos, sin embargo ello no funcionaba con volúmenes de pesca a nivel industrial, lo cual le hizo perder fuerzas y recursos, a pesar de 
ello hasta el año 2010 -año en que realizó dicho balance- asevera que hay empresas nacionales que continúan investigando y desarrollando nuevos productos; al analizar la problemática, indica que ninguno de los diversos intentos por producir a volúmenes industriales el concentrado proteico de pescado u otros productos para el CHD ha llegado al mercado de forma exitosa, al que atribuye las siguientes razones: i) la falta de dispositivos legales adecuados, de promoción, de educación, de tecnologías adecuadas, de desarrollo de sinergias, ii) el tipo de embarcación y bodega, iii) no se ha generado la demanda suficiente que promueva el incentivo económico de proyectos, los cuales también busquen la mejora de procesos, entre otros. El autor menciona un caso particular que vale la pena mencionar, menciona el hecho que las principales empresas peruanas vienen trabajan con pescadores artesanales para obtener anchoveta fresca y en buenas condiciones, ya que la captura realizada por embarcaciones industriales, maltrata el recurso (por la presión del volumen que se ejerce en sus bodegas, pierden frescor debido a la lejanía de las zonas de pesca, las cuales implican un mayor tiempo de navegación, entre otros).Según Alfaro:

[...] en más de cuarenta años no se ha podido redireccionar un porcentaje importante de anchoveta (principal recurso de pesca) al CHD, pese a una serie de esfuerzos de autoridades, empresas, instituciones y pescadores. Un análisis macro de la problemática nos conduce a determinar que el tipo de lanchas, las normas, las técnicas y el tratamiento del pescado, en términos generales, son similares a los que se empleaban hace más de cuatro décadas. En ese sentido, en caso de mantenerse modelos mentales, estructuras y patrones de comportamiento análogos, el resultado será parecido. (2010, p. 36).

A su vez, en el Plan Estratégico Institucional de Ministerio de la Producción (PEI) 2016-2018 aprobado por Resolución de Presidencia del Consejo Directivo $\mathrm{N}^{\circ}$ 26-2014-CEPLAN/PCD, en la que busca potenciar los distintos sectores a nivel nacional, con referencia a la actividad pesquera se menciona que tienen como objetivos promover el aprovechamiento sostenible de los recursos hidrobiológicos, así como incrementar la productividad de la pesca artesanal, Plan en el que se promueve con especial énfasis la productividad artesanal, y para la pesca industrial y/o a gran escala se mencionan medidas correctivas, de sensibilización (tras la comisión de infracciones) o sancionadoras, mas no se refuerzan actividades para éste tipo de pesca, como capacitaciones, promoción 
de la diversificación productiva, entre otros, resalta el tema de la supervisión permanente del cumplimiento de la normativa pesquera y acuícola, cabe precisar que no se observa que se contemplen objetivos específicos para la industria pesquera, como sí los tiene la pesca artesanal.

Respecto a la aplicación del PAS por parte del Ministerio de la Producción al sector empresarial pesquero tenemos que considerar que al aplicarse los subcódigos 18.1 y 18.3 del cuadro de sanciones del TUO del RIPAC, modificado por el Decreto Supremo No 009-2013-PRODUCE, el impacto que se genera en términos económicos a las empresas dedicadas a la pesca industrial afecta la sostenibilidad empresarial. En ese sentido se observa que existe una incompatibilidad entre la aplicación de la sanción y la realidad económica del sector empresarial pesquero, pues considerando que el espíritu de la norma versa que las sanciones buscan identificar falencias en los procesos pesqueros y que posteriormente estas falencias puedan ser corregidas por la empresa.

No obstante, la realidad es que la aplicación de la norma vulnera los principios constitucionales de libertad de empresa, razonabilidad y no confiscatoriedad debido a las exorbitantes cifras que son impuestas al sector pesquero.

Durante el año 2016 la Dirección General de Sanciones (hoy DS-PA) del Ministerio de la Producción bajo las multas establecidas en los sub-coditos 18.1 y 18.3 del cuadro de sanciones del TUO del RISPAC, sancionó a los administrados mediante ochenta y cuatro (84) Resoluciones Directorales por un total de 45,367.905 UIT que significan S/ 179,203,224.75.

Las cifras mencionadas impactan negativamente en el sector empresarial pesquero pues perjudican sus capitales y genera que las empresas apelen las Resoluciones Directorales sancionatorias para ser resueltos por el CONAS y posteriormente de ser confirmadas por la segunda instancia, solicitar la nulidad ante el Poder Judicial, vía Contencioso Administrativo, produciendo sobre carga administrativa, impacto negativo en la administración pública pues al ser multas que vulneran los principios constitucionales mencionados capítulos precedentes no pueden ser amparadas por el Poder Judicial. El Estado como fiscalizador no cumple su función adecuadamente, pues fiscaliza presuntas infracciones con 
multas que no pueden ser exigibles ya que como recaudador no logra hacer eficiente su labor. Este tipo de sanciones tienen impacto negativo en el poder ejecutivo y en el poder judicial al generar carga judicial innecesaria.

Tabla 2.2.

Resumen de Multas 2016

\begin{tabular}{|c|c|c|cc|}
\hline \multicolumn{5}{|c|}{ RESUMEN DE MULTAS 2016 } \\
\hline RÉGIMEN & $\begin{array}{c}\text { MULTA } \\
\text { (UIT) }\end{array}$ & $\begin{array}{c}\mathrm{N}^{\circ} \text { DE } \\
\text { RESOLUCIONES } \\
\text { DIRECTORALES }\end{array}$ & \multicolumn{2}{|c|}{ MULTA (Soles) } \\
\hline DL 25977 & 29865.75 & 37 & S/. & $117,969,712.50$ \\
LEY & 15502.155 & 47 & S/. & $61,233,512.25$ \\
26920 & & 84 & S/. & $179,203,224.75$ \\
\hline TOTAL & 45367.905 & & & \\
\hline
\end{tabular}

Fuente: PRODUCE Elaboración: Propia

Del total de sanciones establecidas durante el año 2016, la Resolución Directoral de sanciones de mayor cuantía en UIT fue la impuesta a la empresa PESQUERA CANTABRIA S.A., ubicada en el departamento de Ancash por un total de 3,193.040 UIT, con un equivalente de S/ 11'814,248 (ONCE MILLONES OCHOCIENTOS CATORCE MIL DOSCIENTOS CUARENTA Y OCHO CON 00/100 SOLES), afecta los capitales de la empresa. 


\section{CAPÍTULO III EL IMPACTO DE LA SANCIÓN HACIA EL SECTOR EMPRESARIAL PESQUERO}

\subsection{Perjuicios económicos al desarrollo empresarial pesquero}

El sector pesquero en el Perú es de vital importancia para el sostenimiento de la economía nacional ya que después de la minería, es el principal ingreso económico para el país. En el año 2008, los desembarques de recursos hidrobiológicos marítimos y continentales significaron más de 2,335 millones de dólares lo que implicó un crecimiento del 19\% respecto al año anterior y el punto más alto de los últimos 20 años.

La captura de los recursos hidrobiológicos en las costas de nuestro país es una actividad de alta rentabilidad para las empresas pesqueras en el rubro industrial, además de generar fuente de ingresos primarios para los pescadores artesanales.

En esta investigación nos hemos centrado en analizar al sector pesquero industrial y comprender como la aplicación de la sanción de los sub-códigos 18.1 y 18.3 del cuadro de sanciones del TUO del RISPAC, modificado por el Decreto Supremo $N^{\circ}$ 009-2013-PRODUCE, descritos en el capítulo anterior afectan los capitales de las empresas pesqueras.

El excesivo valor de las multas genera que las empresas pesqueras rechacen el pago de la misma, solo en el año 2016 se impusieron 84 sanciones de multas por vulneración de los sub-códigos 18.1 y 18.3 del TUO del RISPAC, modificado por el Decreto Supremo N 009-2013-PRODUCE, siendo la de mayor cuantía la ascendente a 3,193.04 UIT, generando impactos negativos a empresas que requieren mantener fluidez de capitales.

En el siguiente gráfico, se observa que de las 84 Resoluciones Directorales sancionadoras de multas impuestas por los sub códigos mencionados existen variaciones considerables en los valores debido a la formula técnica empleada para la aplicación. 
Figura 3.1.

Valor de las multas en UIT del 2016

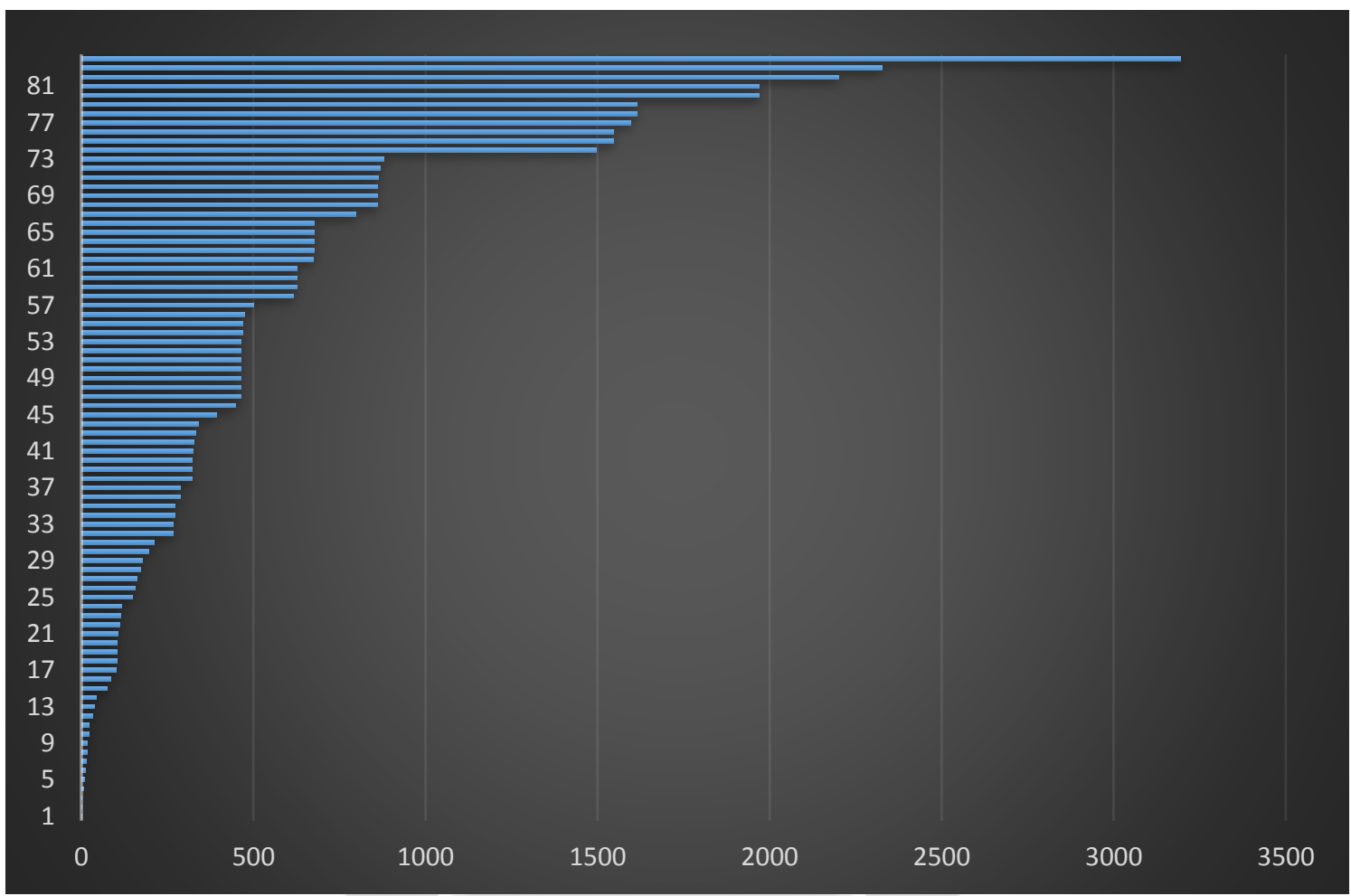

Fuente: Base de datos de PRODUCE. Elaboración: Propia

Si se considera que de los S/ 179,203,224.75, impuestos como multas totales en el 2016 fueron asignados a 84 empresas en diversas partes del país debemos suponer que una multa de estos valores puede desestabilizar económicamente a la empresa o hacerla perder la totalidad de sus capitales y orientarla a declararse en banca rota. Dicho hecho es peligroso para el desarrollo del sector empresarial, pues genera la vulneración de los principios constitucionales de libertad de empresa, razonabilidad y no confiscatoriedad.

Advertir las consecuencias al sector pesquero es importante, pero no solo los privados se encuentran en situación de riesgo con esta norma, sino que el Estado, por su parte, incrementa carga administrativa y se genera sobrecarga judicial generando un gasto adicional a presupuestos establecidos.

Ante esta compleja condición, el sector empresarial pesquero que es sancionado con esta multa se ve en riesgo de pérdida de capitales y genera impactos a la pesca nacional. Según el Ministerio de la Producción, para finales de 2016 se consideraba que el sector pesca crecería un $36 \%$ en relación a su PBI, 
es decir, que si se afecta a un número considerable de empresas y embarcaciones las posibilidades de captura de los recursos hidrobiológicos disminuye y afecta porcentualmente el PBI del sector pesquero, por consecuencia, se afecta los ingresos nacionales.

Tal como se observa, los Sub-códigos analizados están generando impactos en las empresas multadas y, por consecuencia, en el sector empresarial pesquero. Además de impactar colateralmente en la economía nacional.

Ante tal condición, las empresas pesqueras sancionadas presentan resistencia al pago de la multa debido al alto valor de la misma, es por este motivo que buscan a través los recursos de apelación que las Resoluciones Directorales sancionatorias sean revisadas por el CONAS, para luego a través de una demanda de nulidad llevar el expediente al Poder Judicial vía contencioso administrativa, dicho proceso puede extenderse por varios años. En las siguientes páginas se detallará dicha negativa al pago y los argumentos del sector empresarial pesquero.

\subsection{Negativa del sector empresarial pesquero al pago de la sanción de multa}

Tal como se señaló en la sección anterior, durante el 2016 se emitieron 84 Resoluciones Directorales de sanción a las personas naturales o jurídicas (empresas), la causa de la sanción es la infracción al tipo establecido en el numeral 18) del Reglamento de la Ley General de Pesca, aprobado por el Decreto Supremo $\mathrm{N}^{\circ}$ 012-2001-PE, el cual es sancionado con multa bajo las formulas establecidas en los sub-códigos 18.1 y 18.3 , del cuadro de sanciones del TUO del RISPAC, modificado por el Decreto Supremo N 009-2013-PRODUCE.

Debido al elevado monto que significa el pago de la multa, las empresas pesqueras manifiestan su negativa a pagar la obligación, por ello inician procedimientos que buscan dilatar el procedimiento: i) Apelación en vía administrativa; y, ii) Demanda de Nulidad de correspondiente, vía contencioso administrativo en el Poder Judicial.

De la totalidad de las personas naturales o jurídicas (empresas) sancionadas, con las 84 Resoluciones Directorales, la mayoría, presentaron recurso de apelación ante la Dirección de Sanciones quien admite el recurso y lo 
eleva al CONAS, el cual debe resolver en segunda instancia el recurso pudiendo confirmarla o de advertir vicios, declarar la nulidad de la misma.

En caso de que el CONAS confirme la resolución de multa las personas naturales o jurídicas (empresa) pueden acudir a instancias judiciales buscando que se revise el caso. 


\section{CAPÍTULO IV LA RESPUESTA DEL SECTOR EMPRESARIAL PESQUERO ANTE LA IMPOSICIÓN DE LA SANCIÓN DE MULTA}

\subsection{Recurso de Apelación en el procedimiento administrativo sancionador y la demanda de nulidad de la resolución correspondiente por parte del sector empresarial pesquero ante el Poder Judicial (Contencioso Administrativo)}

En el procedimiento administrativo sancionador pesquero los administrados sancionados por la DS-PA, en la mayoría de los casos optan por llevar a la segunda instancia administrativa $y$ al Poder Judicial las Resoluciones Directorales sancionatorias mediante la interposición de recursos de apelación o demandas de nulidad de actos administrativos vía contencioso administrativo.

Una vez notificado con la Resolución Directoral sancionatoria, el administrado de acuerdo a lo estipulado en los artículos $23^{\circ}$ y $45^{\circ}$ del TUO del RISPAC, aprobado por el Decreto Supremo N 019-2011-PRODUCE, en el plazo de quince (15) días hábiles, puede interponer recurso de apelación identificando el número de la mencionada resolución, ante la DS-PA de acuerdo a lo establecido en el literal e) del artículo $89^{\circ}$ del Reglamento de Organización y Funciones del Ministerio de la Producción, aprobado por el Decreto Supremo $\mathrm{N}^{\circ}$ 002-2017-PRODUCE, la cual previa evaluación del mencionado recurso, lo admite y lo eleva al CONAS en su calidad de superior jerárquico, el cual de acuerdo a mencionado en el literal a) del artículo $126^{\circ}$ del mencionado Reglamento, resuelve el recurso de apelación interpuesto con arreglo a la normativa vigente sobre la materia, precisando que en atención a lo tipificado en el artículo $46^{\circ}$ del TUO del RISPAC, el citado órgano de apelación con su resolución emitida agota la vía administrativa.

Posteriormente, si de la evaluación del recurso de apelación el CONAS resuelve confirmar la Resolución Directoral sancionatoria emitida por la DS-PA, el administrado sancionado de acuerdo a lo previsto en el primer numeral de los artículos $4^{\circ}$ y $5^{\circ}$, en concordancia con lo establecido en el artículo $10^{\circ}$ del Texto 
Único Ordenado de la Ley que regula el Proceso Contencioso Administrativo, de considerarlo puede presentar su demanda de nulidad del acto administrativo, en el caso en concreto sobre la Resolución emitida por el CONAS, ante el Juez en lo contencioso administrativo del lugar del domicilio del demandado o del lugar donde se produjo la actuación de la materia.

\subsection{El Control Difuso como mecanismo de resolución de controversias}

Tal como advierte Rubio (2008) con relación a los alcances del control difuso administrativo desde la institución jurídica, sería difícil la aplicación en nuestro ordenamiento jurídico del mismo, ya que no existe competencia expresa y precisa, otorgada a las entidades del Estado para aplicar ésta facultad, como sí la poseen los jueces y magistrados. En ese sentido, Rubio (2008) en el análisis que realiza sobre el pronunciamiento del Tribunal Constitucional (en el marco de la causa seguida en el Expediente $\mathrm{N}^{\circ}$ 3471-2004-AA/TC, resalta el hecho que Pando ${ }^{1}$ advierte sobre la inaplicación de normas legales inconstitucionales al indicar que la Administración se encuentra sujeta al principio de legalidad, y que un funcionario de la Administración puede obrar en torno a lo que la Ley le permite hacer, es decir, que está impedido de hacer lo que la Ley no le faculta y a su vez la Ley como norma de inferior jerarquía a la Constitución, debe ser acorde a ésta última, sin embargo, tal como manifiesta Rubio (2008) la Administración no se encuentra facultada de interpretar lo que es o no inconstitucional, dejar de aplicarla o pronunciarse en sentido contrario a ella porque ésta debe garantizar ejercer sus funciones en el marco de la Ley. En éste sentido, se comparte la postura de Rubio (2008) al manifestar que, si bien en la actualidad la Administración no puede derogar ni declarar inconstitucional una Ley, sin perjuicio de su cumplimiento puede solo examinarla y proponer canales de derecho para su derogación a pesar de que la inconstitucionalidad sea manifiesta, por ello propone que:

[...] la Administración dentro del marco de la constitución debe utilizar o proponer la creación de mecanismos que permitan autorizarla, con seguridad jurídica, a implicar una ley a un caso concreto, pero mientras ello no se dé, tiene la obligación de cumplir la ley mientras se encuentre vigente. (Rubio 2008:74) 
A su vez, para comprender el control difuso administrativo desde la perspectiva del Tribunal Constitucional, debe tomarse en cuenta que la Administración Pública, se encuentra sometida de manera directa a la Constitución, y al principio de legalidad, también Rubio al analizar los presupuestos del Tribunal contenidos en el artículo VI del Título Preliminar del Código Procesal Constitucional, observa que:

[...] el Tribunal Constitucional estima que la Administración Pública, a través de sus órganos colegiados, no solo tiene la facultad de hacer cumplir la Constitución....sino también el deber constitucional de realizar el control difuso de las normas que sustentan los actos administrativos y que son contrarias a la Constitución o a la interpretación que de ella haya realizado el Tribunal Constitucional. (Rubio 2008: 75)

Además, que si bien en el artículo $138^{\circ}$ de la Constitución, se reconoce a los jueces la potestad de ejercer control difuso, de allí no se deriva que solo los jueces pueda/deba realizarse en el marco de un proceso judicial, se comparte al igual que Rubio (2008) la postura de que el control difuso debe ser ejercido por todas las entidades del Estado, considerando el principio de supremacía constitucional previsto en el artículo $138^{\circ}$ de la Constitución, en el cual el Tribunal Constitucional ha establecido mecanismos para el ejercicio del mismo, dentro del cual entre diversas opiniones manifiesta que son los órganos colegiados o tribunales administrativos quienes imparten justicia o que resuelven controversias, los cuales deben tener competencia nacional, así como estar adscritos al Poder Ejecutivo, donde el Control Difuso debe ser solicitado de parte, y donde el tribunal administrativo de manera excepcional deberá ejercer de oficio el control difuso, si encuentra que una norma es inconstitucional, a no ser que la norma legal que pretende observar haya sido previamente ratificada en procesos constitucionales. En el actual contexto, tal como asevera (Rubio 2008) es difícil la viabilidad del control difuso a nivel administrativo por múltiples razones, las cuales fueron descritas en las primeras líneas, pero básicamente se comparte la postura de la dificultad de ejercer la misma desde la Administración pública ya que la flexibilidad del principio de legalidad como ha sido planteado por el Tribunal puede generar un caos, sin perjuicio de lo anteriormente señalado se considera en la presente investigación que el control difuso administrativo 
puede ser aplicable si se establece un nuevo marco reglamental (el cual termina teniendo carácter de ley) en el cual se establezcan parámetros que faculten a la máxima autoridad evaluadora a nivel administrativo del Ministerio de la Producción, a poder ejercer el control difuso "tras la solicitud de la empresa multada" en casos particulares en los cuales se determine o se presuma la incompatibilidad entre lo legal, es decir entre lo establecido en los reglamentos o normas, y lo constitucional. Se comparte a su vez, la postura de Castillo (2007) contenida en el análisis de Rivas (2010) el cual manifiesta que la Administración se vincula a la Constitución a través de criterios hermenéuticos que se desprenden del control de la constitucionalidad que estos realicen (Castillo 2007. En: Rivas 2010: 89), a su vez es la Constitución la que fija parámetros para el accionar, pero también fija el punto de partida para las actuaciones jurídicas, así como para las diversas regulaciones sectoriales del Derecho deberían confluir, porque ninguna ley, sentencia judicial o acto administrativo podría contener disposiciones que contravengan con lo estipulado en la Constitución realicen (Del Pozo 2007 En Rivas 2010: 92), en ese sentido interpretativo la Administración en la actualidad no está facultada para declarar la constitucionalidad o inconstitucionalidad de tal o cual ley, ya que ello le corresponde a un ente judicial, sin embargo, tal como señala Bullard e Higa (2007), si bien una ley otorga facultades a las agencias, no puede negarle la posibilidad de poner en vigencia los derechos que la propia Constitución reconoce, en ese sentido si una ley vulnera el sistema económico o los derechos fundamentales de la persona humana, de por sí, ello ya es inconstitucional, y por ende inaplicable. Estos autores señalan:

Una ley no debería establecer que los tribunales administrativos no pueden hacer control difuso, pues ello estaría vulnerando la lógica misma de la resolución de conflictos intersubjetivos, en los que los ciudadanos tienen derecho a la aplicación del sistema legal en su conjunto, incluida la Constitución, y las leyes. (Bullard e Higa, 2007. En: Rivas: 2010, 95)

Finalmente se comparte la postura de Rivas (2010) al indicar que si se debe atribuir a la Administración Publica la aplicación del control difuso, pero de manera bastante limitada y racional, por ello se considera que el máximo órgano evaluador del Ministerio de la Producción debería ser un órgano colegiado que 
tenga independencia en sus decisiones, lo cual le permitirá estar facultado para ejercer funciones cuasi jurisdiccionales, todo ello con la finalidad de garantizar derechos fundamentales de los administrados al resolver los casos concretos que se les presenten. Ello no resulta alejado de la realidad, ya que tal como indica Rivas.

[...] Los tribunales administrativos, si bien pertenecen o están adscritos al poder ejecutivo, estos ejercen funciones cuasi jurisdiccionales de manera independiente y con autonomía, resolviendo conflictos entre los administrados y la administración. Claro ejemplo de esto es el Tribunal Fiscal, que resuelve en última instancia administrativa conflictos entre los contribuyentes y la Administración tributaria, donde emite resoluciones muy poco cuestionables en la vía jurisdiccional. (Rivas: 2010:97) 


\section{CONCLUSIONES}

- En la elaboración del Decreto Supremo Nº 009-2013-PRODUCE, que modifico las fórmulas de las sanciones de multa de los Sub-códigos 18.1 y 18.3 del cuadro de sanciones del Texto Único Ordenado del Reglamento de Inspecciones y Sanciones Pesqueras y Acuícolas, los órganos competentes del Ministerio de la Producción, utilizaron una deficiente técnica legislativa, lo cual devino en la problemática de la imposición de multas de cuantía exorbitante y desproporcional.

- Actualmente de acuerdo a la Constitución Política, se cuenta con un mecanismo dual de control de la constitucionalidad de la normas, el Control Concentrado y el Control Difuso ejercidos por el Tribunal Constitucional en caso de ambos y los jueces del Poder Judicial en caso del segundo, sin embargo el 14 de noviembre de 2005, vía jurisprudencial con la emisión de la STC N 3741-2004-AA/TC y Aclaratoria, en el caso Salazar Yarleque, el supremo interprete de la constitución integro al ordenamiento jurídico peruano el Control Difuso Administrativo, ejercido por tribunales u órganos colegiados de la Administración Publica de alcance nacional, sin embargo después de casi ocho (08) años de vigencia, el 18 de marzo de 2014, mediante la STC N 4293-2012-PA/TC, se puso fin al Control Difuso Administrativo. 


\section{RECOMENDACIONES}

- Con el objeto de solucionar la problemática de las cuantías exorbitantes y desproporcionales de las sanciones de multas, respecto de la aplicación de los Subcódigos 18.1 y 18.3 del cuadro de sanciones del Texto Único Ordenado del Reglamento de Inspecciones y Sanciones Pesqueras y Acuícolas, modificados por el Decreto Supremo $N^{\circ}$ 009-2013-PRODUCE, proponemos la emisión de un nuevo Reglamento de Inspecciones y Sanciones Pesqueras y Acuícolas, utilizando los paramentos estipulados en la Ley $\mathrm{N}^{\circ}$ 26889, Ley Marco para la Producción y Sistematización Legislativa y su reglamento aprobado por el Decreto Supremo $\mathrm{N}^{\circ}$ 008-2006-JUS, así como los alcances de la Guía de Técnica Legislativa para la elaboración de Proyectos Normativos de las Entidades del Poder Ejecutivo, aprobado por la Resolución Directoral $N^{\circ}$ 007-2016-PRODUCE, en especial los aspectos referidos a: i) Exposición de motivos, ii) Análisis costo beneficio; y, iii) Análisis de impacto de la vigencia de la norma en la legislación nacional.

- La habilitación por parte del Tribunal Constitucional del Control Difuso Administrativo, bajo un mecanismo igual de revisión y consulta como el establecido igual al establecido en el artículo $14^{\circ}$ de la Ley Orgánica del Poder Judicial, aprobado por el Decreto Supremo 017-93-JUS, con el objeto de a través del mencionado mecanismo de control, se uniformice la jurisprudencia administrativa referida a la inaplicación de una norma por ser inconstitucional. 


\section{REFERENCIAS}

Alfaro, L (2010) Perú, país marítimo. 1st ed. Lima: CENTRUM Publishing, pp. 15-23. Recuperado de:

http://www2.congreso.gob.pe/sicr/cendocbib/con4_uibd.nsf/8B3C17E2F E336FF905257B4400745BE8/\$FILE/14_PERU_PA\%C3\%8DS_MARITI MO.pdf

Arias Koga, Luis (2015) El Control Difuso Administrativo y sus implicancias en el Estado Constitucional de Derecho. Tesis para optar el título de abogado de la facultad de Derecho de la Universidad de Piura, 2015.

Asamblea Constituyente (1979) Constitución Política del Perú. Recuperado el 12-05-2017

http://www4.congreso.gob.pe/comisiones/1999/simplificacion/const/197 $\underline{9 . h t m}$

Baca, Víctor (2009) La Administración Publica y el control difuso de la constitucionalidad de las leyes en la jurisprudencia reciente del Tribunal Constitucional peruano. Gaceta Constitucional N 23.

Capcha, Olivia (2011) Los Principios del Procedimiento Administrativo Sancionador como Garantías del Administrado frente a la Facultad Punitiva del Estado. Manual de la Ley del Procedimiento Administrativo General. Gaceta Jurídica. Lima, pp. 183-208.

Coloma, Germán (2001) Análisis Económico del Derecho Privado y Regulatorio. Buenos Aires: Editorial Ciudad Argentina.

Congreso Constituyente Democrático (1993) Constitución Política del Perú. Recuperado el 12-05-2017

http://www4.congreso.gob.pe/comisiones/1996/constitucion/cons1993.ht $\underline{\mathrm{m}}$

Decreto Legislativo $N^{\circ} 1047$, Ley de Organización y Funciones del Ministerio de la Producción (25 de junio de 2008) Recuperado del sitio de internet Palestra Editores:

http://www.palestraeditores.com/upload/uf/7f9/7f96dae892a838f301071c c5d6a2a368.pdf

Decreto Ley $N^{\circ}$ 25977, Ley General de Pesca (10 de julio de 2013) Recuperado del sitio de internet de SENACE:

https://www.senace.gob.pe/download/senacenormativa/NAS-4-8-01-DLEY-25977.pdf

Decreto Supremo N 008-2006-JUS, Reglamento de la Ley Marco para la Producción y Sistematización Legislativa (9 de diciembre de 1997) 
Recuperado del sitio de internet del Ministerio de Justicia:

http://docs.peru.justia.com/federales/leyes/26889-dec-9-1997.pdf

Decreto Supremo N 012-2001-PE, Reglamento de la Ley General de Pesca (13 de marzo de 2001) Recuperado del sitio de internet de la Sociedad Nacional de Pesquería: http://www.snp.org.pe/d-s-012-2001-pereglamento-de-la-ley-general-de-pesca/

Decreto Supremo N ${ }^{\circ}$ 264-2012-EF, Valor de la Unidad Impositiva Tributaria durante el año 2013 (19 de diciembre de 2012) Recuperado del sitio de internet del Diario Oficial El Peruano:

http://busquedas.elperuano.com.pe/normaslegales/valor-de-la-unidadimpositiva-tributaria-durante-el-ano-2013-decreto-supremo-n-264-2012ef-880785-8/

$\mathrm{DL} \mathrm{N}^{\circ}$ 1272, Modificatoria de Ley del Procedimiento Administrativo General $\mathrm{N}^{\circ} 27444$ (20 de diciembre de 2016) Recuperado del sitio de internet del Diario Oficial El Peruano:

http://busquedas.elperuano.com.pe/normaslegales/decreto-legislativoque-modifica-la-ley-n-27444-ley-del-pr-decreto-legislativo-n-1272$1465765-1 /$

DS 013-2008-JUS, Texto Único Ordenado de la Ley N²7584 (29 de agosto de 2008) Recuperado del sitio de internet:

https://scc.pj.gob.pe/wps/wcm/connect/3d9480004d90b2898711f7db524a 342a/D.+Sup.+13-2008+JUS+-

+TUO+Ley+que+regula+el+Proceso+Contencioso+Administrativo.pdf? $\underline{\text { MOD=AJPERES\&CACHEID=3d9480004d90b2898711f7db524a342a }}$

DS N 001-2014-PRODUCE, Reglamento del Sistema de Seguimiento Satelital para embarcaciones pesqueras (SISESAT) ( 9 de junio de 2014) Recuperado del sitio de internet del Ministerio de la Producción: http://www2.produce.gob.pe/dispositivos/publicaciones/ds001-2014produce.pdf

DS N ${ }^{\circ}$ 002-2017-PRODUCE, Reglamento de Organización y Funciones del Ministerio de la Producción (1 de febrero de 2017) Recuperado del sitio de internet del Diario Oficial El Peruano:

http://busquedas.elperuano.com.pe/normaslegales/decreto-supremo-queaprueba-el-reglamento-de-organizacion-y-decreto-supremo-n-002-2017produce-1481180-3/

DS N 006-2017-JUS, Texto Único Ordenado de la Ley del Procedimiento General Administrativo (17 de marzo de 2017) Recuperado del sitio de internet del Diario Oficial El Peruano:

http://busquedas.elperuano.com.pe/normaslegales/decreto-supremo-queaprueba-el-texto-unico-ordenado-de-la-le-decreto-supremo-n-006-2017jus-1498863-6/

DS N009-2013-PRODUCE, que modifica el Reglamento de la Ley general de Pesca y el Texto Único Ordenado del Reglamento de Inspecciones y 
Sanciones Pesqueras y Acuícolas, a efectos de disminuir la captura de ejemplares en tallas o pesos menores a los autorizados (30 de octubre de 2013) Recuperado del sitio de internet del Ministerio de la Producción: http://www2.produce.gob.pe/dispositivos/publicaciones/ds009-2013produce.pdf

DS N 017-93-JUS, Texto Único Ordenado de la Ley Orgánica del Poder Judicial (02 de junio de 1993) Recuperado del sitio de internet de la Organización de Estados Americanos: http://www.oas.org/juridico/PDFs/mesicic4_per_ds017.pdf

DS N ${ }^{\circ}$ 019-2011-PRODUCE, Texto Único Ordenado del Reglamento de Inspecciones y Sanciones Pesqueras y Acuícolas (02 de diciembre de 2011) Recuperado del sitio de internet del Ministerio de la Producción: http://www2.produce.gob.pe/dispositivos/publicaciones/2011/diciembre/ ds019-2011-produce.pdf

DS N ${ }^{\circ}$ 026-2003-PRODUCE, Reglamento de Seguimiento Satelital SISESAT (31 de octubre de 2013) Recuperado del sitio de internet del Ministerio de la Producción:

http://www2.produce.gob.pe/dispositivos/publicaciones/rm326-2013produce.pdf

Espinoza- Saldaña, Eloy (2009) "Notas sobre el algunas veces confuso escenario del control difuso en el Perú". En: Gaceta Constitucional ํ⒔

Espinoza- Saldaña, Eloy (2014) El control de constitucionalidad. (06 de junio de 2014). [mensaje en un blog] Recuperado de: http://blog.pucp.edu.pe/blog/christianguzmannapuri/2014/06/06/el-control-deconstitucionalidad/

García, Juan Antonio (2008) "Controles descontrolados y precedentes sin precedente. A propósito de la sentencia del Tribunal Constitucional del Perú en el Exp. N`3741-2004-AA/TC (Caso Salazar Yarlenque) En: JUS Constitucional, Num 1, 2008, pp. 75-99.

Gutiérrez, Walter (2013) La constitución comentada. Lima: Gaceta Jurídica.

Guzmán, Christian (2016) Manual del Procedimiento Administrativo General. Lima: Pacifico.

Huamán, Alberto (2008) “Judicial Review en los tribunales administrativos e igualdad en el procedimiento administrativo según la STC Exp. $\mathrm{N}^{\circ}$ 06135-2006-PA/TC. Retos desde su elasticidad propugnada por el Tribunal Constitucional peruano en defensa de los derechos fundamentales del administrado". EN: Gaceta Constitucional, Num. 7, pp.311-322.

Huamán, Elmer (2008) "El Control Difuso en sede administrativa” EN: Ita lus Esto, Revista virtual de estudiantes de la Universidad de Piura, num 1, pp. 200-214. 
INEI (14 de mayo de 2017) Informe técnico $\mathrm{N}^{\circ}$ 04. Recuperado de http://www.inei.gob.pe/media/MenuRecursivo/boletines/04-informetecnico-n04_produccion-nacional-feb2017.pdf

Ley $\mathrm{N}^{\circ}$ 26821, Ley Orgánica de Aprovechamiento Sostenible de los Recursos Naturales (26 de junio de 1997) Recuperado del sitio de internet de la Autoridad Nacional del Agua:

http://www.ana.gob.pe/media/95192/ley_26821.pdf

Ley $\mathrm{N}^{\circ}$ 26889, Ley Marco para la Producción y Sistematización Legislativa

Ley $\mathrm{N}^{\circ} 26920$, Ley que exceptúa del requisito de incremento de flota al que se refiere el artículo $24^{\circ}$ de la Ley General de Pesca, a aquellos armadores que cuenten con embarcaciones de madera de hasta $110 \mathrm{~m} 3$ (11 de julio de 2014) Recuperado del sitio de internet del Ministerio de la Producción:

http://www2.produce.gob.pe/dispositivos/publicaciones/dgepp/2011/Juli o/RD-420-2011-PRODUCE-DGEPP.pdf

Ley $\mathrm{N}^{\circ}$ 27444, Ley del Procedimiento General Administrativo (21 de marzo de 2001) Recuperado del sitio de internet de la Presidencia del Consejo de Ministros: http://www.pcm.gob.pe/wp-content/uploads/2013/09/Ley-deProcedimiento-Administrativo-de-PersonalLey27444.pdf

Ley $\mathrm{N}^{\circ}$ 27658, Ley Marco de Modernización de la Gestión del Estado (29 de enero de 2002) Recuperado del sitio de internet del Instituto de Investigación y Capacitación Municipal:

http://www.inicam.org.pe/normativa/legislacion/Ley27658.pdf

Ley $\mathrm{N}^{\circ}$ 28237, Código Procesal Constitucional (7 de mayo de 2004)

Recuperado del sitio de internet del Tribunal Constitucional

http://www.tc.gob.pe/tc/private/adjuntos/institucional/normatividad/codi go_procesal.pdf

Ley $\mathrm{N}^{\circ} 27584$, Ley que regula el Proceso Contencioso Administrativo (22 de noviembre de 2011) Recuperado del sitio de internet del Congreso de la República:

http://www4.congreso.gob.pe/comisiones/2001/justicia/ley27584.htm

Meza, Mosi (2014) Control Difuso Administrativo Peruano. Tesis para optar el grado académico de Maestro en Derecho Constitucional de la Escuela de Post Grado de la Pontificia Universidad Católica del Perú.

Morón, Juan Carlos (2010) "El control de legalidad a cargo de la Administración y el control difuso en sede administrativa. Comentarios a la STC Exp. N00014-2009-PI/TC”: Gaceta Constitucional, Num, 33, pp.278-282.

Ochoa, Cesar (2014) "El control difuso en sede administrativa, el fin de un precedente" EN: Gaceta Constitucional y Procesal Constitucional. 
PRODUCE Ministerio de la Producción. (12 de abril de 2017) Plan estratégico Institucional PEI, 2016- 2018. Recuperado de:

http://www2.produce.gob.pe/dispositivos/publicaciones/rm216-2016produce.pdf

Quiroga, Aníbal (2010) Anuario de Derecho Constitucional Latinoamericano. S/E:Montevideo.

Resolución Directoral N 007-2016-JUS/DGDOJ, Guía Técnica Legislativa para la Elaboración de Proyectos Normativos de las Entidades del Poder Ejecutivo ( ) Recuperado del sitio de internet del Ministerio de Justicia: https://www.minjus.gob.pe/procedimientosadministrativos-sancionadores/

Resolución Directoral N ${ }^{\circ}$ 3351-2016-PRODUCE/DGS, la cual sanciona a empresa PESQUERA CANTABRIA S.A. (20 de mayo de 2016) Recuperado del sitio de internet del Ministerio de Producción: http://www2.produce.gob.pe/dispositivos/publicaciones/2005/dinsecovi/ DGS/RD2016/3300-3399/RD\%203351-2016-PRODUCE-DGS.pdf

Resolución Ministerial N 163-2017-PRODUCE, Disponen la publicación, en el Portal Institucional del Ministerio, del proyecto de Decreto Supremo que aprueba el Reglamento de Fiscalización y Sanción de las Actividades Pesqueras y Acuícolas, así como su exposición de motivos (10 de abril de 2017) Recuperado del sitio de internet del Diario Oficial El Peruano: http://busquedas.elperuano.com.pe/normaslegales/disponen-lapublicacion-en-el-portal-institucional-del-mini-resolucion-ministerial-n163-2017-produce-1508000-2/

Rojas, Héctor (2014) Los principios constitucionales limitadores del Ius Puniendi ¿Qué límites rigen el Derecho Administrativo Sancionador en el Perú? Tesis para optar el grado de maestro en Derecho. PUCP: Lima.

Rubio, César (2008) "El Control Difuso Administrativo en el ordenamiento jurídico peruano. Algunos alcances a propósito del pronunciamiento del tribunal Constitucional" EN: Revista Jurídica del Perú, Num. 86, pp. 7982.

Salas, Pedro (2006) 10 Años de Sentencias Claves del Tribunal Constitucional en Diversas Materias del Derecho. Lima: Gaceta Jurídica.

SNP

Sociedad Nacional de Pesquería (25 de Abril del 2017). Lima, Perú: Sociedad Nacional de Pesquería. Recuperado de https://www.snp.org.pe/exportaciones-pesqueras/

STC N ${ }^{\circ}$ 00003-2006-PI/TC (Lima). (2006). Tribunal Constitucional: Pleno del Tribunal Constitucional. Recuperado del sitio de internet del Tribunal Constitucional: http://www.tc.gob.pe/jurisprudencia/2006/00003-2006$\underline{\text { AI.html }}$ 
STC N ${ }^{\circ}$ 00014-2009-PI/TC (Lima). (2010). Tribunal Constitucional: Pleno del Tribunal Constitucional. Recuperado del sitio de internet del Tribunal Constitucional: http://www.tc.gob.pe/jurisprudencia/2010/00014-2009$\underline{\text { AI.html }}$

STC N ${ }^{\circ}$ 0041-2004-AI/TC (Lima). (2004). Tribunal Constitucional: Pleno del Tribunal Constitucional. Recuperado del sitio de internet del Tribunal Constitucional: http://www.tc.gob.pe/jurisprudencia/2005/00041-2004AI.html

STC N 007-2001-AI-TC (Lima). (2003). Tribunal Constitucional: Pleno del Tribunal Constitucional. Recuperado del sitio de internet del Tribunal Constitucional: http://www.tc.gob.pe/jurisprudencia/2003/00007-2001$\underline{\text { AI.html }}$

STC N 01124-2001-AA (Lima). (2002). Tribunal Constitucional: Pleno del Tribunal Constitucional. Recuperado del sitio de internet del Tribunal Constitucional: http://www.tc.gob.pe/jurisprudencia/2002/01124-2001$\underline{\text { AA.html }}$

STC N 01405-2010-PA/TC (Lima). (2010). Tribunal Constitucional: Pleno del Tribunal Constitucional. Recuperado del sitio de internet del Tribunal Constitucional: http://www.tc.gob.pe/jurisprudencia/2011/01405-2010$\underline{\text { AA.html }}$

STC N ${ }^{\circ}$ 03330-2004-AA/TC (Lima). (2005). Tribunal Constitucional: Pleno del Tribunal Constitucional. Recuperado del sitio de internet del Tribunal Constitucional: http://tc.gob.pe/jurisprudencia/2005/03330-2004$\underline{\text { AA.html }}$

STC N 1492-2003-AA/TC (Lima). (2004). Tribunal Constitucional: Pleno del Tribunal Constitucional. Recuperado del sitio de internet del Tribunal Constitucional: http://www.tc.gob.pe/jurisprudencia/2005/01492-2003$\underline{\text { AA.html }}$

STC N ${ }^{\circ}$ 2302-2003-AA/TC (Lima). (2005). Tribunal Constitucional: Pleno del Tribunal Constitucional. Recuperado del sitio de internet del Tribunal Constitucional: http://www.tc.gob.pe/jurisprudencia/2005/02302-2003AA.html

STC N 3741-2004-AA/TC (Lima). (2005). Tribunal Constitucional: Pleno del Tribunal Constitucional. Recuperado del sitio de internet del Tribunal Constitucional: http://www.tc.gob.pe/jurisprudencia/2006/03741-2004$\underline{\text { AA.html }}$

STC N 4227-2005-PA/TC (Lima). (2006). Tribunal Constitucional: Pleno del Tribunal Constitucional. Recuperado del sitio de internet del Tribunal Constitucional: http://www.tc.gob.pe/jurisprudencia/2006/04227-2005$\underline{\text { AA.html }}$ 
STC N 4293-2012-PA/TC (Lima). (2014). Tribunal Constitucional: Pleno del Tribunal Constitucional. Recuperado del sitio de internet del Tribunal Constitucional: http://www.tc.gob.pe/jurisprudencia/2014/04293-2012$\underline{\text { AA.pdf }}$

Tamayo, Paul (2014) Análisis de la compatibilidad del sistema de sanciones en el sector eléctrico con la Ley del Procedimiento Administrativo General. Un estudio de caso. Tesis para optar el grado de maestro Regulación de Servicios Públicos. PUCP: Lima.

Tirado, José Antonio (2008) “¿Debe la administración inaplicar una Ley por inconstitucional?: tres argumentos en contra del control difuso administrativo" EN: Jorge Danós El derecho administrativo y la modernización del Estado peruano. Ponencias presentadas en el Tercer Congreso Nacional de derecho Administrativo. Lima: Grijley, pp. 163 178.

Vergaray, Verónica y Hugo Gómez (2009) “Sobre la Ley del Procedimiento Administrativo General." En: Maravi, Milagros Libro Homenaje a José Alberto Bustamante Lima: UPC.

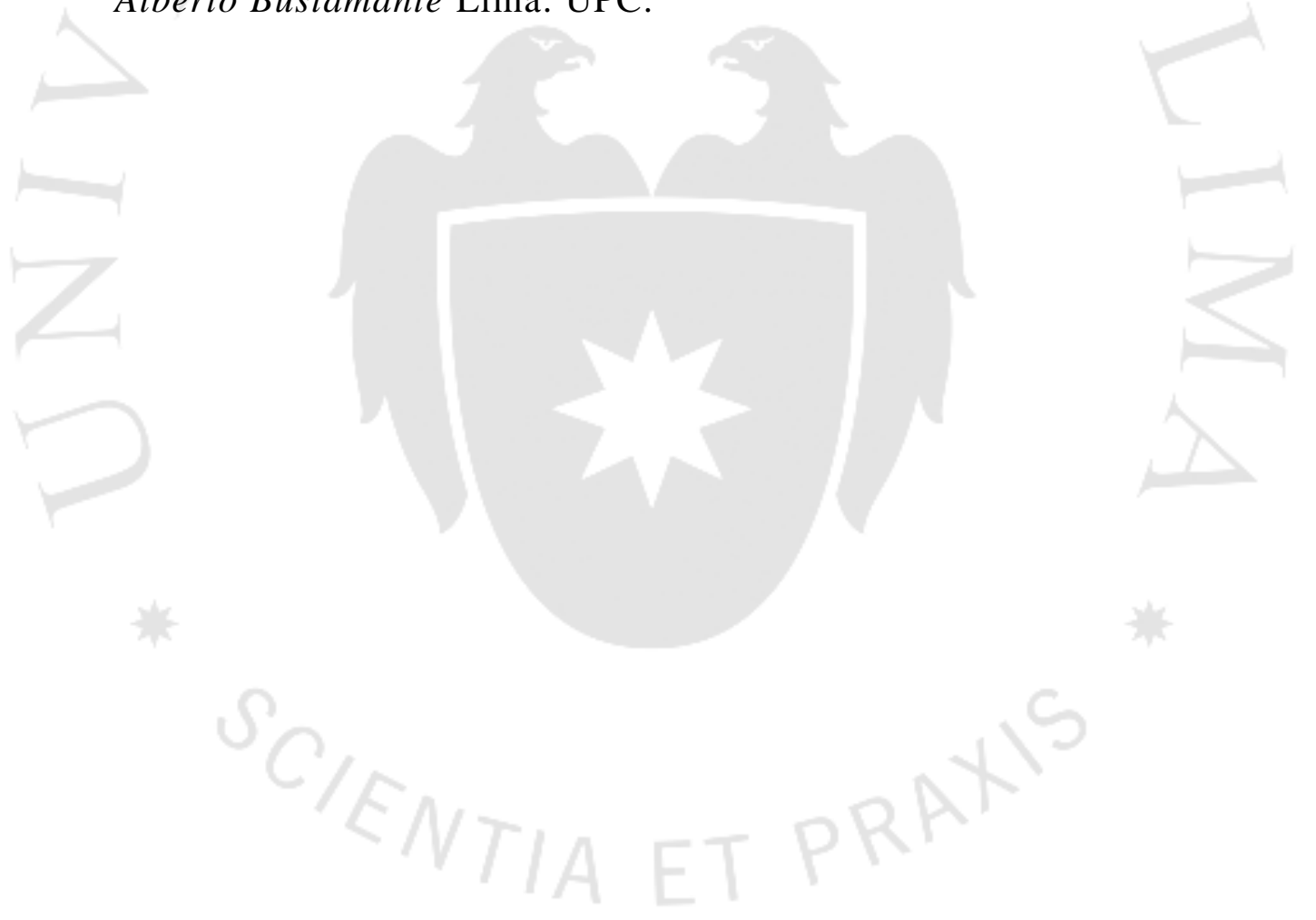

